\title{
Nudibranch molluscs of the genus Dendronotus Alder et Hancock, 1845 (Heterobranchia: Dendronotina) from Northwestern Sea of Japan with description of a new species
}

\author{
I.A. Ekimova ${ }^{1,2}$, D.M. Schepetov ${ }^{3,4,5}$, O.V. Chichvarkhina ${ }^{6}$, \\ A.Yu. Chichvarkhin 2,6 \\ ${ }^{1}$ Biological Faculty, Moscow State University, Leninskiye Gory 1-12, 119234 Moscow, Russia. \\ E-mail: irenekimova@gmail.com \\ ${ }^{2}$ Far Eastern Federal University, Sukhanova Str. 8, 690950 Vladivostok, Russia. \\ ${ }^{3}$ Koltzov Institute of Developmental Biology RAS, Vavilov Str. 26, 119334 Moscow, Russia. \\ ${ }^{4}$ Russian Federal Research Institute of Fisheries and Oceanography, V. Krasnoselskaya Str. 17, \\ 107140 Moscow, Russia. \\ ${ }^{5}$ National Research University Higher School of Economics, Myasnitskaya Str. 20, 101000 \\ Moscow, Russia. \\ ${ }^{6}$ A.V. Zhirmunsky Institute of Marine Biology, Russian Academy of Sciences, Palchevskogo Str. 17, \\ 690041 Vladivostok, Russia.
}

ABSTRACT: Species of the genus Dendronotus are among the most common nudibranchs in the northern Hemisphere. However, their distribution and composition in the North-west Pacific remain poorly explored. In the present study, we observed Dendronotus composition in northwestern part of the Sea of Japan, using an integrative approach, included morphological and molecular phylogenetic analyses and molecular species delimitation methods. These multiple methods revealed high cryptic diversity within the genus. Two specimens of Dendronotus frondosus were found in Amursky Bay and therefore its amphiboreal status was confirmed. In three locations of the Sea of Japan we found specimens, which are very close externally to $D$. frondosus, but show significant distance according to molecular analysis. We show that these specimens belong to a new species Dendronotus dudkai sp.n. This species is sister to D. frondosus according to morphological and molecular data, therefore the question of sympatric coexistence is discussed. For the first time Dendronotus kamchaticus was registered in the Sea of Japan and updated information of some intraspecific variation of this species is provided.

How to cite this article: Ekimova I.A., Schepetov D.M., Chichvarkhina O.V., Chichvarkhin A.Yu. 2016. Nudibranch molluscs of the genus Dendronotus Alder et Hancock, 1845 (Heterobranchia: Dendronotina) from Northwestern Sea of Japan with description of a new species // Invert. Zool. Vol.13. No.1. P.15-42. doi: 10.15298/invertzool.13.1.02

KEY WORDS: Nudibranchia, northwestern Pacific, species delimitation, molecular phylogeny, integrative taxonomy, Mollusca. 


\title{
Голожаберные моллюски рода Dendronotus Alder et Hancock, 1845 (Heterobranchia: Dendronotina) Северо-Восточной части Японского моря, с описанием нового вида
}

\author{
И.А. Екимова ${ }^{1,2}$, Д.М. Щепетов ${ }^{3,4,5}$, О.В. Чичвархина ${ }^{6}$, \\ А.Ю. Чичвархин ${ }^{2,6}$
}

\footnotetext{
${ }^{1}$ Биологический факультет, Московский государственный университет им. М.В. Ломоносова, Ленинские горы 1-12, 119234, Москва, Россия.

${ }^{2}$ Дальневосточный федеральный университет, ул. Суханова, 8, 690950, Владивосток, Россия.

${ }^{3}$ Институт биологии развития им. Н.К. Кольцова РАН, ул. Вавилова 26, 119334, Москва, Россия.

${ }^{4}$ Всероссийский научно-исследовательский институт рыбного хозяйства и океанографии, Красносельская ул. 17, 107140, Москва, Россия.

${ }^{5}$ Национальный университет «Высшая школа экономики», Мясниикая ул., 101000 Москва, Россия.

${ }^{6}$ Институт биологии моря им. А.В. Жирмунского РАН, ул. Пальчевского 17, 690041 Владивосток, Россия.
}

РЕЗЮМЕ: Виды рода Dendronotus являются одними из наиболее обычных голожаберных моллюсков в северном полушарии. Тем не менее, их распространение и таксономический состав в северо-западной части Тихого океана остается слабо изученным. Нами был исследован таксономический состав рода Dendronotus в северо-западной части Японского моря с использованием комплексного подхода, включающего морфологический и молекулярно-филогенетический анализы, а также методы молекулярного разделения видов. Было выявлено высокое криптическое разнообразие видов рода Dendronotus. Две особи Dendronotus frondosus были обнаружены в Амурском Заливе и, таким образом, было подтверждено его амфибореальное распространение. В трех локациях Японского моря нами также были обнаружены особи, сходные с $D$. frondosus по признакам внешней морфологии, однако резко отличные по молекулярным данным от всех исследованных видов рода Dendronotus. Показано, что данные особи относятся к новому для науки виду Dendronotus dudkai sp.n. и дано его подробное описание. Ввиду того, что D. frondosus и $D$. dudkai sp.n. являются близкими сестринскими видами, обсуждается вопрос о их симпатрическом происхождении и сосуществовании. Впервые вид D. kamchaticus был зарегистрирован в Японском море. Приведена обновленная информация о некоторых внутривидовых вариациях данного вида.

Как цитировать эту статью: Ekimova I.A., Schepetov D.M., Chichvarkhina O.V., Chichvarkhin A.Yu. 2016. Nudibranch molluscs of the genus Dendronotus Alder et Hancock, 1845 (Heterobranchia: Dendronotina) from Northwestern Sea of Japan with description of a new species // Invert. Zool. Vol.13. No.1. P.15-42. doi: 10.15298/invertzool.13.1.02

КЛЮЧЕВЫЕ СЛОВА: Nudibranchia, северо-западная часть Тихого океана, анализ видовых границ, молекулярная филогения, интегративная таксономия, Mollusca. 


\section{Introduction}

Nudibranch genus Dendronotus Alder et Hancock, 1845 is distributed mostly in northern Hemisphere and includes approximately 20 extant valid species that are among the most common shallow-water bottom marine invertebrates (Wägele et al., 2013; Ekimova et al., 2015; Gofas, Bouchet, 2015). Until recently, type species of the genus Dendronotus frondosus (Ascanius, 1774) was commonly regarded as amphiboreal species, with a very broad range extending from European seas and the Arctic Ocean to California and Chile (Robilliard, 1970, 1975; Behrens, 1980; McDonald, 1983, 2009; Roginskaya, 1987; Behrens, 1991; Schrödl, 2003). In the mid-20th century Frank Mace MacFarland (MacFarland, 1966) described several more North Pacific species of this genus including Dendronotus albus MacFarland, 1966, D. subramosus MacFarland, 1966 and D. venustus MacFarland, 1966. The diversity and distinctness of the North American Dendronotus species were studied in a detailed morphological review of this genus (Robilliard, 1970). D. venustus was commonly regarded as a synonym of the Atlantic D. frondosus, even in the North American literature (McDonald, 2009).

The use of molecular markers caused considerable changes in the taxonomy of northern and Arctic species. The first molecular study of the genus (Stout et al., 2010) showed minor but reliable differences between Pacific and Atlantic populations of $D$. frondosus. The MacFarland's name $D$. venustus was therefore restored. The validity of North Atlantic species D. lacteus (Thompson, 1840) was confirmed based on allosyme electrophoresis and morphological data (Thollesson, 1998). Few other North American species e.g. D. nanus Marcus et Marcus, 1967 and $D$. diversicolor Robilliard, 1970 were instead shown to be synonyms of $D$. iris Cooper, 1963 and D. albus, respectively (Stout et al., 2010). Another North Pacific species D. patricki Stout, Wilson et Valdes, 2011 has been described from the deep sea off California (Stout et al., 2011). Pseudobornella orientalis (Baba, 1932) from Japan was transferred from the genus Pseudobornella Baba, 1932 to Dendronotus based on concatenated molecular analyses of three genes (Pola, Gosliner, 2010). A recent study conducted by Ekimova et al. (2015) revealed three new species of the genus from Arctic and northwestern Pacific: D. kalikal Ekimova, Korshunova, Schepetov, Neretina, Sanamyan et Martynov, 2015, D. kamchaticus Ekimova, Korshunova, Schepetov, Neretina, Sanamyan et Martynov, 2015, and D. niveus Ekimova, Korshunova, Schepetov, Neretina, Sanamyan et Martynov, 2015. In addition, it has been proposed that the highly variable species D. frondosus is restricted only to the North Atlantic boreal and subarctic waters, while in the North-West Pacific it could be represented by a complex of several cryptic species.

For a long time $D$. frondosus has been reported from northwestern waters of the Sea of Japan (Roginskaya, 1987; Martynov, 1999, 2006; Martynov, Korshunova, 2011; Chernyshev, 2014) and from the Sado isl near Honshu (Baba, 1993). D. frondosus was also discovered at Starichkov isl (the North-West Pacific, Kamchatka peninsula) (Martynov et al., 2010); however this data was reconsidered after the description of D. kamchaticus and D. kalikal (Ekimova et al., 2015). Dendronotus sp. was also reported from all northwestern Pacific seas (Martynov, 1997, 2013). The latest work by Martynov et al. (2015) provided a new information on Dendronotus species composition in northwestern part of the Sea of Japan. A new species D. primorjensis Martynov, Sanamyan et Korshunova, 2015 was described. However, its taxonomic description is too poor and does not contribute any necessary information for species delimitation. Authors also referred to molecular analysis of cytochrome $c$ oxidase subunit I (COI) gene, that could prove the $D$. primorjensis validity, but no sequences have been published via GenBank or BOLD and no phylogenetic trees have been provided in the paper. The $D$. primorjensis description is quite similar to the original description of $D$. venustus (MacFarland, 1966) and the latest redescription of D. frondosus (Ekimova et al., 2015). Moreover, previous findings of D. frondosus or Dendronotus sp. in the Sea of Japan have not been 


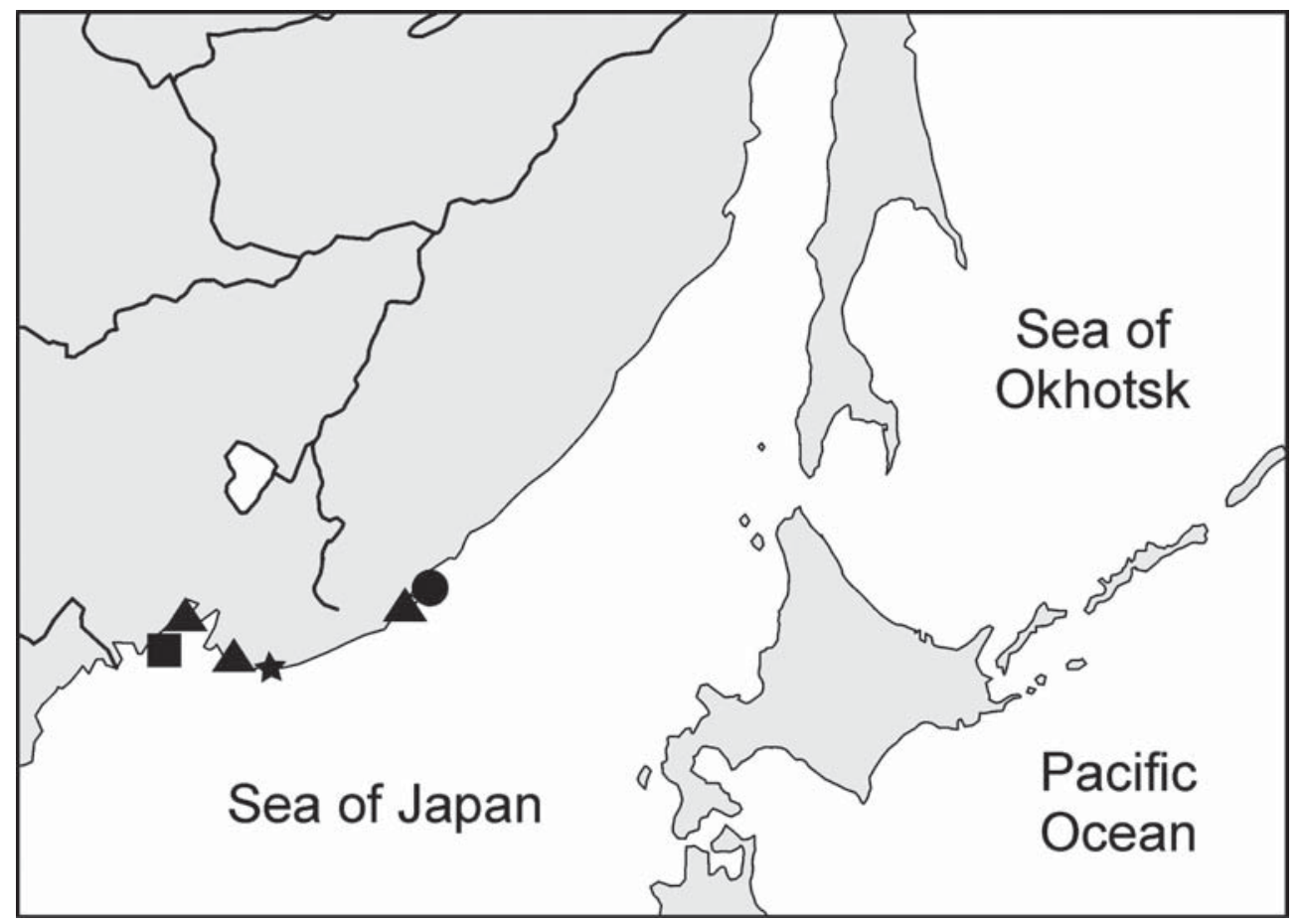

Fig. 1. Map of the north part of the Sea of Japan showing collecting sites of $D$. dudkai sp.n. (triangles), $D$. frondosus (quadrate), D. kamchaticus (circle). Star matches the type locality of $D$. primorjensis.

Рис. 1. Карта северной части Японского моря с местами сбора $D$. dudkai sp.n. (треугольники), $D$. frondosus (квадрат), D. kamchaticus (круг). Звездочкой отмечено типовое местонахождение $D$. primorjensis.

considered as minor synonyms of $D$. primorjensis (Martynov et al., 2015). In these cases, the composition of " $D$. frondosus species complex" in the Sea of Japan seems to be disordering and requires a major revision. The present paper attempts to provide morphological and molecular data to clarify the taxonomic status of $D$. frondosus, D. primorjensis and Dendronotus sp. in northwestern Sea of Japan.

\section{Material and Methods}

Due to the difficulties of the genus Dendronotus taxonomic studies using traditional methods (e.g. ontogenetic variations, colouration pattern variations and high level of other intraspecific differences), we followed the integrative approach, represented in Ekimova et al. (2015). It includes molecular phylogenetic meth- ods, molecular species delimitation methods and detailed morphological studies with an analysis of the postlarval ontogenetic variations.

\section{Sampling data}

Juvenile and adult specimens probably belonging to species $D$. frondosus with egg masses were obtained for this study by SCUBA diving and snorkeling during May-October 2013-2015 in Amursky, Rudnaya, and Vostok Bays of the Sea of Japan (Fig. 1). Living specimens were photographed with Nikon D300 and D810 cameras with Nikkor $60 /$ f2.8D or Tokina $100 /$ f2.8D lens. Underwater imaging was conducted using Sea\&Sea MDX-D810 housing and two Sea\&Sea YS-D1 strobes. All specimens were photographed individually and then preserved in $96 \%$ or $70 \%$ ethanol at ambient temperature before DNA or morphological analyses were performed 
respectively. Type meterial is deposited in Zoological Museum of Lomonosov Moscow State University (ZMMU). Other material is deposited in a subsidiary of ZMMU at the White Sea Biological Station (vouchers and barcode collections - W and WS respectively).

\section{Molecular analysis}

13 specimens of the genus Dendronotus from different localities were used for the mo- lecular analysis. Previously published sequences of different Dendronotus species from GenBank (with voucher numbers LACM - Museum of Natural History, Los Angelos, USA, CASIZ - Californian Academy of Science, San Francisco, USA, SIO - Scripps Institute of Oceanology, and ZMMU) were also used to place the new species in a phylogenetic framework (Table 1). Specimens of Scyllaeidae, Dotoidae and Tritoniidae were included as outgroups (according to Ekimova et al., 2015).

Table 1. Specimens used for molecular analysis with GenBank accession numbers. Markings indicate new sequences obtained for this study. Таблица 1. Особи, использованные для молекулярного анализа с регистрационными номерами ГенБанка. Выделенные номера обозначают новые сиквенсы, полученные в ходе настоящего исследования.

\begin{tabular}{|c|c|c|c|c|c|}
\hline Species & Locality & Voucher & $\mathrm{COI}$ & $16 \mathrm{~S}$ & $28 \mathrm{~S}$ \\
\hline $\begin{array}{l}\text { Dendronotus } \\
\text { albopunctatus }\end{array}$ & Washington & - & GQ292064 & - & - \\
\hline D. albus & California & LACM174845 & - & GU339185 & - \\
\hline D. dalli & Kamchatka & ZMMU Op-294 & КC660023 & KC611294 & KC660007 \\
\hline D. dalli & Kamchatka & ZMMU Op-295 & KM397001 & KM397083 & KM397042 \\
\hline D. dalli & Kamchatka & ZMMU Op-330 & KM396999 & KM397081 & KM397040 \\
\hline D. dalli & Kamchatka & ZMMU Op-331 & KM397000 & KM397082 & KM397041 \\
\hline D. dalli & NW Atlantic & - & AF249800 & AF249252 & AY427450 \\
\hline D. dudkai sp.n. & Sea of Japan & W195 & KT031811 & KT031824 & KT031841 \\
\hline D. dudkai sp.n. & Sea of Japan & W196 & KT031812 & KT031825 & KT031842 \\
\hline D. dudkai sp.n. & Sea of Japan & W197 & KT031813 & KT031826 & KT031843 \\
\hline D. dudkai sp.n. & Sea of Japan & W198 & KT031814 & KT031827 & KT031844 \\
\hline D. dudkai sp.n. & Sea of Japan & W199 & KT031815 & KT031828 & KT031845 \\
\hline D. dudkai sp.n. & Sea of Japan & W201 & KT031816 & KT031829 & KT031837 \\
\hline D. dudkai sp.n. & Sea of Japan & W202 & KT031817 & KT031830 & KT031838 \\
\hline D. dudkai sp.n. & Sea of Japan & W202 & KT031818 & KT031831 & KT031840 \\
\hline D. dudkai sp.n. & Sea of Japan & ZMMU Lc-40366 & KT031819 & KT031832 & KT031839 \\
\hline D. iris & Washington & LACM174471 & GQ292062 & GU339189 & - \\
\hline D. frondosus & White Sea & ZMMU Op-290 & KC660028 & KC611280 & KC660008 \\
\hline D. frondosus & Norway & ZMMU Op-380 & KM396976 & KM397056 & KM397017 \\
\hline D. frondosus & Barents Sea & ZMMU Op-298 & KM396985 & KM397067 & KM397025 \\
\hline D. frondosus & Barents Sea & ZMMU Op-299 & KM396984 & KM397066 & KM397026 \\
\hline D. frondosus & White Sea & ZMMU Op-317 & KM396978 & KM397060 & KM397019 \\
\hline D. frondosus & Barents Sea & ZMMU Op-291 & KC660030 & KC611281 & KC660009 \\
\hline D. frondosus & Barents Sea & ZMMU Op-292 & KC660031 & KC611282 & KC6600010 \\
\hline D. frondosus & White Sea & ZMMU Op-293 & KC660029 & KC611283 & KC6600011 \\
\hline D. frondosus & Barents Sea & ZMMU Op-324 & KM396980 & KM397062 & KM397021 \\
\hline D. frondosus & Barents Sea & ZMMU Op-325 & KM396981 & KM397063 & KM397022 \\
\hline D. frondosus & Barents Sea & ZMMU Op-326 & KM396982 & KM397064 & KM397023 \\
\hline D. frondosus & Barents Sea & ZMMU Op-327 & KM396983 & KM397065 & KM397024 \\
\hline D. frondosus & Barents Sea & ZMMU Op-359 & KM396979 & KM397061 & KM397020 \\
\hline D. frondosus & Barents Sea & ZMMU Op-382 & KM396977 & KM397050 & KM397018 \\
\hline
\end{tabular}


Table 1 (continued). Таблица 1 (продолжение).

\begin{tabular}{|c|c|c|c|c|c|}
\hline Species & Locality & Voucher & $\mathrm{COI}$ & $16 \mathrm{~S}$ & $28 \mathrm{~S}$ \\
\hline $\begin{array}{l}\text { Dendronotus } \\
\text { frondosus }\end{array}$ & Sea of Japan & W204 & KT031820 & KT031833 & KT031846 \\
\hline D. frondosus & Sea of Japan & W205 & KT031821 & KT031834 & KT031847 \\
\hline D. kalikal & Kamchatka & ZMMU Op-349 & KM396986 & KM397068 & KM397027 \\
\hline D. kalikal & Kamchatka & ZMMU Op-283 & KC660024 & KC611284 & KC660012 \\
\hline \multirow{3}{*}{ D. kalikal } & \multirow{3}{*}{ Kamchatka } & \multirow{3}{*}{ ZMMU Op-284 } & KC660025 & KC611286 & KC660013 \\
\hline & & & KC660026 & KC611285 & KC660014 \\
\hline & & & KM396988 & KM397070 & KM397029 \\
\hline D. kalikal & Bering Strait & ZMMU Op-285 & KC660027 & KC611287 & KC660015 \\
\hline D. kamchaticus & Kamchatka & ZMMU Op-245 & KC660032 & KC611288 & KC660016 \\
\hline \multirow{3}{*}{ D. kamchaticus } & \multirow{3}{*}{ Kamchatka } & \multirow{3}{*}{ ZMMU Op-246 } & KC660033 & KC611289 & KC660017 \\
\hline & & & KM396989 & KM397071 & KM397030 \\
\hline & & & KM396990 & KM397072 & KM397031 \\
\hline \multirow{2}{*}{ D. kamchaticus } & \multirow{2}{*}{ Kamchatka } & \multirow{2}{*}{ ZMMU Op-247 } & KM396991 & KM397073 & KM397032 \\
\hline & & & KM396992 & KM397074 & KM397033 \\
\hline D. kamchaticus & Sea of Japan & W194 & KT031822 & KT031835 & KT031848 \\
\hline D. kamchaticus & Sea of Japan & W194 & KT031823 & KT031836 & KT031849 \\
\hline D. lacteus & Barents Sea & ZMMU Op-286 & KC660034 & KC611290 & KC660018 \\
\hline D. lacteus & Barents Sea & ZMMU Op-287 & KC660035 & KC611291 & KC660019 \\
\hline \multirow{2}{*}{ D. lacteus } & \multirow{2}{*}{ Norway } & \multirow{2}{*}{ ZMMU Op-383 } & KM396971 & KM397054 & KM397012 \\
\hline & & & KM396972 & KM397055 & KM397013 \\
\hline D. lacteus & Barents Sea & ZMMU Op-288 & KM396975 & KM397059 & KM397016 \\
\hline D. lacteus & Barents Sea & ZMMU Op-333 & KM396974 & KM397058 & KM397015 \\
\hline D. lacteus & Barents Sea & ZMMU Op-335 & KM396973 & KM397057 & KM397014 \\
\hline D. niveus & White Sea & WS1102 & KC660036 & KC611292 & КС660020 \\
\hline D. niveus & White Sea & WS2005 & KM396998 & KM397080 & KM397039 \\
\hline D. niveus & White Sea & ZMMU Op-269 & KM396996 & KM397078 & KM397037 \\
\hline D. niveus & White Sea & ZMMU Op-270 & KM396997 & KM397079 & KM397038 \\
\hline \multirow{3}{*}{ D. niveus } & \multirow{3}{*}{ Barents Sea } & \multirow{3}{*}{ ZMMU Op-274 } & KC660037 & KC611293 & KC660021 \\
\hline & & & KM396993 & KM397076 & KM397034 \\
\hline & & & KM396994 & KM397075 & KM397035 \\
\hline D. niveus & Barents Sea & ZMMU Op-279 & KM396995 & KM397077 & KM397036 \\
\hline D. orientalis & China & CASIZ174989 & - & HM162628 & - \\
\hline D. patricki & California & $\begin{array}{l}\text { SIO-BIC } \\
\text { M12134 }\end{array}$ & HQ225828 & HQ225829 & - \\
\hline D. regius & Philippines & CASIZ179492 & JN869451 & HM162629 & - \\
\hline D. robustus & Barents Sea & ZMMU Op-343 & KM397002 & KM397084 & KM397043 \\
\hline D. robustus & Barents Sea & ZMMU Op-344 & KM397003 & KM397085 & KM397044 \\
\hline \multirow{5}{*}{ D. robustus } & \multirow{5}{*}{ Barents Sea } & \multirow{5}{*}{ ZMMU Op-390 } & KM396963 & KM397045 & KM397004 \\
\hline & & & KM396964 & KM397046 & KM397005 \\
\hline & & & KM396965 & KM397047 & KM397006 \\
\hline & & & KM396966 & KM397048 & KM397007 \\
\hline & & & KM396968 & KM397051 & KM397009 \\
\hline D. robustus & Barents Sea & ZMMU Op-391 & KM396970 & KM397053 & KM397011 \\
\hline D. robustus & Barents Sea & ZMMU Op-392 & KM396967 & KM397049 & KM397008 \\
\hline D. robustus & Barents Sea & ZMMU Op-393 & KM396969 & KM397052 & KM397010 \\
\hline D. robustus & Barents Sea & ZMMU Op-391 & KM396970 & KM397053 & KM397011 \\
\hline D. rufus & Alaska & LACM174861 & - & GU339191 & - \\
\hline D. subramosus & Washington & LACM174855 & - & GU339197 & - \\
\hline D. venustus & California & LACM174852 & HM162709 & GU339199 & - \\
\hline
\end{tabular}


Table 1 (continued). Таблица 1 (продолжение).

\begin{tabular}{|l|c|c|c|c|c|}
\hline \multicolumn{1}{|c|}{ Species } & Locality & Voucher & COI & $16 \mathrm{~S}$ & 28S \\
\hline Doto coronata & South Africa & CASIZ 176278 & AF249794 & HM162657 & - \\
\hline D. koenneckeri & Portugal & CASIZ178247 & HM162735 & AF249249 & - \\
\hline $\begin{array}{l}\text { Notobryon } \\
\text { thompsoni }\end{array}$ & Philippines & CASIZ176362 & JM869455 & JN869413 & - \\
\hline N. wardi & South Africa & CASIZ177540 & HM162714 & HM162639 & - \\
\hline Scyella fulva & Philippines & CASIZ182823 & JN869458 & JN869415 & - \\
\hline $\begin{array}{l}\text { Janolus } \\
\text { barbarensis }\end{array}$ & California & CASIZ176833 & HM162747 & HM162671 & - \\
\hline
\end{tabular}

Table 2. PCR and sequencing primers.

Таблица 2. Праймеры, использованные для ПЦР и секвенирования.

\begin{tabular}{|l|l|l|}
\hline Name & $5^{\prime}-3^{\prime}$ & References \\
\hline $16 \mathrm{~S}$ arL & CGCCTGTTTAACAAAAACAT & Palumbi et al. 1991 \\
\hline 16S R & CCGRTYTGAACTCAGCTCACG & Puslednik \& Serb (2008) \\
\hline LCO 1490 & GGTCAACAAATCATAAAGATATTGG & Folmer et al. 1994 \\
\hline HCO 2198 & TAAACTTCAGGGTGACCAAAAAATCA & Folmer et al. 1994 \\
\hline $28 \mathrm{~S} \mathrm{C1}{ }^{\prime}$ & ACCCGCTGAATTTAAGCAT & Lê et al. 1993 \\
\hline 28SC2 & TGAACTCTCTCTTCAAAGTTCTTTTC & Lê et al. 1993 \\
\hline
\end{tabular}

DNA was extracted from small pieces of foot tissue using Diatom ${ }^{\mathrm{TM}}$ DNA Prep $100 \mathrm{kit}$ by Isogene according to the manufacturer's protocol. Extracted DNA was used as a template for amplification of cytochrome $c$ oxidase subunit I (COI), 16S rRNA and C1-C2 domain of 28S rRNA. The primers that were used for amplification are shown in Table 2. Polymerase chain reaction amplifications were carried out in a 20$\mu \mathrm{L}$ reaction volume, which included $4 \mu \mathrm{L}$ of $5 \mathrm{x}$ Screen Mix by Eurogen Lab, $0.5 \mu \mathrm{L}$ of each primer (10 $\mu \mathrm{M}$ stock), $1 \mu \mathrm{L}$ of genomic DNA and $14 \mu \mathrm{L}$ of sterile water. The amplification of COI and 28S was performed with an initial denaturation for $1 \mathrm{~min}$ at $95^{\circ} \mathrm{C}$ followed by 35 cycles of $15 \mathrm{~s}$ at $95^{\circ} \mathrm{C}$ (denaturation), $15 \mathrm{~s}$ at $45^{\circ} \mathrm{C}$ (annealment) and $30 \mathrm{~s}$ at $72{ }^{\circ} \mathrm{C}$ with a final extension of $7 \mathrm{~min}$ at $72{ }^{\circ} \mathrm{C}$. The $16 \mathrm{~S}$ amplification began with an initial denaturation for $1 \mathrm{~min}$ at $95^{\circ} \mathrm{C}$ followed by 40 cycles of 15 $\mathrm{s}$ at $95^{\circ} \mathrm{C}$ (denaturation), $15 \mathrm{~s}$ at $52{ }^{\circ} \mathrm{C}$ (annealment), $30 \mathrm{~s}$ at $72{ }^{\circ} \mathrm{C}$ with a final extension of 7 $\min$ at $72{ }^{\circ} \mathrm{C}$. Sequencing for both strands proceeded with the Big Dye v3.1 sequencing kit by Applied Biosystems. Sequencing reactions were analized using ABI 3500 Genetic Analyser (Ap- plied Biosystems) in N.K. Koltsov Institute of Developmental Biology (Moscow, Russia). All new sequences were deposited in GenBank. Raw reads for each gene were assembled and checked for improper base-calling using GeneiousPro 4.8.5. Original data and publicly available sequences were aligned with MUSCLE (Edgar, 2004) algorithm in MEGA 6 (Tamura et al., 2013) software. Protein-coding sequences were translated into amino acids for confirmation of the alignment. The resulting alignments were of $641 \mathrm{bp}$ for COI, $471 \mathrm{bp}$ for 16S, $350 \mathrm{bp}$ for $28 \mathrm{~S}$. Individual gene analyses, separate mitochondrial and nuclear gene analyses, and a concatenated analysis were performed in this study. The best-fitting nucleotide evolution models were tested in MEGA 6 toolkit using Bayesian information criterion (BIC). The $28 \mathrm{~S}$ partition scored the lowest BIC for the Hasegawa-Kishino-Yano model. The best-fitting model for COI and 16S partitions was General Time Reversible model with a gamma distribution and a fraction of sites being invariable. Phylogeny reconstructions of individual gene datasets were conducted by maximum likelihood method, implemented in MEGA 6 with 2000 boot- 
strap pseudoreplications and in MrBayes 3.2 (Ronquist, Huelsenbeck, 2003). Reconstructions based on combined datasets (mitochondrial, nuclear, and concatenated analyses) were performed applying evolutionary models for partitions separately. The Bayesian estimation of posterior probability was also performed in MrBayes 3.2. Markov chains were sampled at intervals of 500 generations. The analysis was started with random starting trees and $10^{7}$ generations. Maximum likelihood-based phylogeny inference for all combined data sets was performed in GARLI 2.0 (Zwickl, 2006) with bootstrap in 1000 pseudoreplications. Bootstrap values were placed on the best tree found with SumTrees 3.3.1 from DendroPy Phylogenetic Computing Library Version 3.12.0 (Sukumaran, Mark, 2010). Final phylogenetic tree images were rendered in FigTree 1.4.0.

\section{Species delimitation}

We used three methods to define species: comparing single- and combined-gene tree topologies, Automatic Barcode Gap Discovery (ABGD) and Generalized Mixed Yule Coalescent method (GMYC). Single- and combinedgene trees were calculated using MEGA 6 and MrBayes 3.2 as explained above. ABGD method (Puillandre et al., 2012) is based on pairwise distances, detecting the breaks in the distribution referred to as the "barcode gap" (Herbert et al., 2003) without any prior species hypothesis. It is commonly used for species delimitation analyses, including the latest works on opisthobranch taxa (Jörger et al., 2012; Barco et al., 2013; Jörger, Schrödl, 2013; Krug et al., 2013; Camara et al., 2014; Carmona et al., 2014a, b; Churchill et al., 2014; Ortigosa et al., 2014, Padula et al., 2014; Goodheart et al., 2015; Ekimova et al., 2015 and others). The ABGD program is available at web site http:// wwwabi.snv.jussieu.fr/public/abgd/abgdweb. html. We analyzed COI and $16 \mathrm{~S}$ alignments separately (excluding outgroups) using both proposed models: Jukes-Cantor (JK69) and Kimura (K80). In the case of COI, $\mathrm{P}_{\text {max }}$ was increased to 0.20 and amount of steps was increased to 15 . Other settings were remained default. In $16 S$ analysis, the default settings were used. GMYC method proposed by Pons (Pons et al., 2006) and observed by Fujisawa \& Barraclough (Fujisawa, Barraclough, 2013), is also rather popular in species delimitation studies (Neusser et al., 2011; Williams et al., 2011; Falniowski, Szarowska, 2012; Jörger et al., 2012; Prévot et al., 2013; Fontaneto, 2014; Fontaneto et al., 2014, and others). Approaches based on the GMYC model rely on the expectation that intraspecific coalescent branching proceeds discernibly quicker than speciation, which is modelled as a Yule process. Therefore, species can be identified in genes tree as clusters of terminals separated by longer internal branches. It requires a fully dichotomous and rooted ultrametric tree without duplicate sequences based on single-gene analyses. The tree was run using BEAST (Drummond, Rambaut, 2007) and then analyzed within the R environment, following instructions represented by Fujisawa \& Barraclough (2013).

\section{Morphological data}

The external morphology of molluscs was studied under a stereomicroscope. For the description of internal features preserved specimens were dissected under the stereomicroscope. The buccal mass of each specimen was extracted and soaked in 10\% sodium hypochlorite solution for 1-2 minutes to dissolve connective and muscle tissue, leaving only the radula and jaws. The features of the jaws of each species were analyzed under the stereomicroscope and scanning electron microscope and then drawn. The coated radulae were examined and photographed using scanning electron microscopes CamScan, JEOL JSM or EVO-40 Zeiss. Reproductive systems of different species were also examined and drawn using the stereomicroscope.

\section{Results}

\section{Molecular analysis}

We acquired 39 original nucleotide sequences for 13 specimens of the genus Dendronotus 


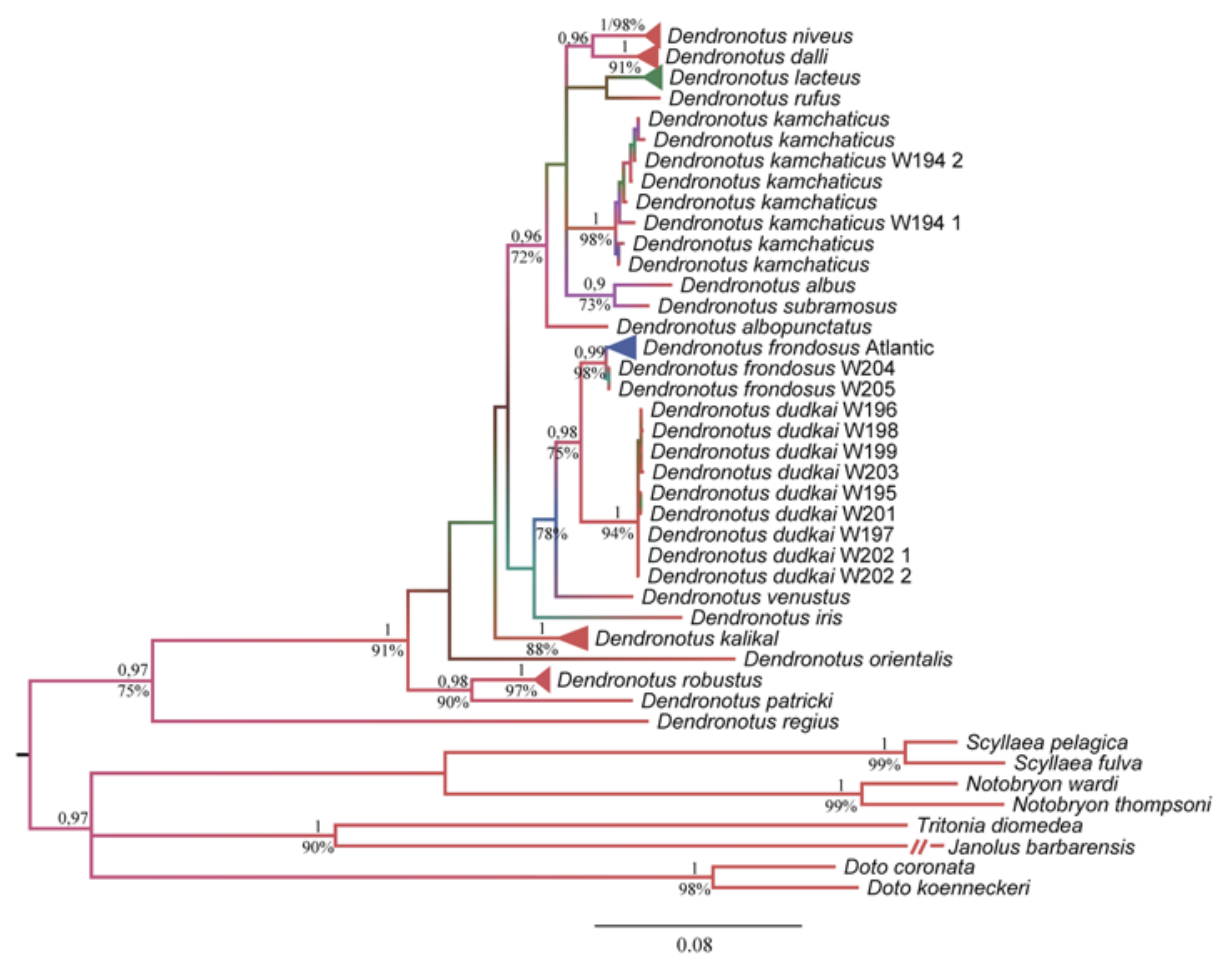

Fig. 2. Phylogenetic hypothesis based on combined molecular data $(\mathrm{COI}+16 \mathrm{~S}+28 \mathrm{~S})$ represented by Bayesian inference, species-level branches collapsed excluding Dendronotus dudkai sp.n., D. frondosus and D. kamchaticus clades. First numbers on branches represent posterior probabilities from Bayesian inference; second numbers indicate bootstrap values for Maximum likelihood.

Рис. 2. Байесовская (МСMC) филогенетическая гипотеза, основанная на объединенных последовательностях (COI+16S+28S), клады видового уровня слиты, кроме клад Dendronotus dudkai sp.n., D. frondosus и D. kamchaticus. Над ветвями указаны апостериорные вероятности Байесовского анализа (BI) и индексы бутстрепа (1000 псевдореплик), полученные при реконструкции филогенетического древа методом максимального правдоподобия (ML).

from northwestern part of the Sea of Japan. The combined data set including three loci was presented in a sequence alignment of 1462 codon positions. Single-gene (not shown), combined mitochondrial trees (not shown) and concatenated tree (Fig. 2) showed same topology, however the nodes support in nuclear single-gene and combined trees was low. The topology of concatenated tree based on Bayesian analysis was congruent with consensus Maximum likelihood tree in most cases, but some branches in ML have low support (Fig. 2). Dendronotus monophyly was rather weakly supported by Bayesian Inference and Maximum Likelihood $(\mathrm{PP}=0.97, \mathrm{BS}=75 \%)$. However, all species of
Dendronotus excluding tropical $D$. regius form a high supported group $(\mathrm{PP}=1, \mathrm{BS}=91 \%)$. Our data shows that Dendronotus specimens from the Sea of Japan are separated into three wellsupported, reciprocally monophyletic clades. Two specimens from Rudnaya Bay (W194) are in the same clade as type specimens of $D$. kamchaticus $(\mathrm{PP}=1, \mathrm{BS}=98 \%)$. Two specimens, collected in Amursky Bay (W204, W205) truly belong to the species $D$. frondosus $(\mathrm{PP}=$ 0.99 , BS $=98 \%$ ). However, other nine specimens (W195-W203, W206-W207) form a separate clade from other species of the genus ( $\mathrm{PP}=$ $1 ; \mathrm{BS}=94 \%$ ). This group clusters together with Pacific species D. venustus and Atlantic and 
Pacific specimens of $D$. frondosus ( $\mathrm{PP}=0.98$, $\mathrm{BS}=75 \%$ ), but $D$. venustus shows more basal placement. Other clades confirm the monophyly of species-level groups. Deepwater $D$. patric$k i$ and $D$. robustus turned out to be a sibling species ( $\mathrm{PP}=0.98, \mathrm{BS}=90 \%)$ and show most basal position with $D$. regius and $D$. orientalis. The other branch includes a large group of northern shallow-water species $(\mathrm{PP}=0.97, \mathrm{BS}$ $=76 \%$ ). Within this group, three major clades can be distinguished. The first one includes $D$. kalikal, the second includes $D$. iris and sister to it $D$. frondosus $+D$. venustus + Dendronotus sp. (Voucher numbers W195-W203, W206W207) ( $\mathrm{PP}=1, \mathrm{BS}=74 \%)$. The third clade includes D. albopunctatus, D. albus, D. dalli, D. kamchaticus (GenBank specimens and W194), D. lacteus, D. niveus, D. rufus and D. subramosus $(\mathrm{PP}=0.96, \mathrm{BS}=73 \%)$. The relationships within these clades remain unresolved.

\section{Species delimitation}

ABGD analysis of COI dataset, running with two different models, revealed 13 potential species each: D. robustus, D. frondosus (GenBank specimens and W204, W205), D. lacteus, D. kalikal, D. kamchaticus (GenBank specimens and W194), D. niveus, D. dalli, D. venustus, D. iris, D. albopunctatus, D. patricki, D. regius and Dendronotus sp. (W195-W203, W206-207). ABGD analysis of 16 S dataset revealed 17 potential species each: Dendronotus sp. (W195-W203, W206-W207), D. robustus, D. frondosus (GenBank specimens and W204, W205), D. lacteus, D. kalikal, D. kamchaticus (GenBank specimens and W204, W205), D. niveus, D. dalli, D. venustus, D. iris, D. albus, D. orientalis, D. patricki, D. subramosus, D. rufus and D. regius. The prior maximum distance ranged between 0.001 and 0.0116 for COI. In the case of $16 \mathrm{~S}$, the prior maximum distance ranged between 0.0012 and 0.0058 . Differences in number of potential species in each analysis are determined by lacking of COI data for some NE Pacific species. GMYC analysis of COI marker recovers 13 species units. These independent molecular delimitation ap-
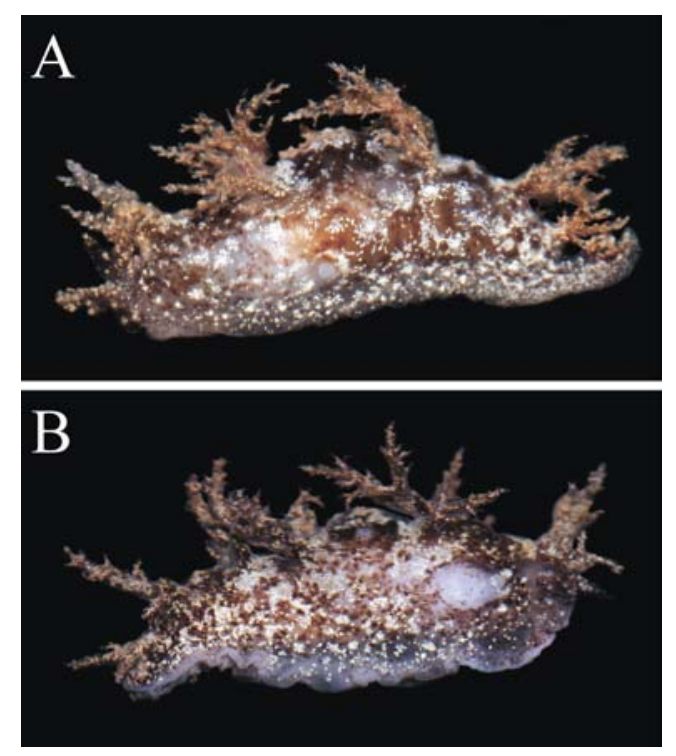

Fig. 3. Dendronotus frondosus, living animals. A W204, specimen $16 \mathrm{~mm}$ in length, lateral view from the left. B - W205, specimen $19 \mathrm{~mm}$ in length, lateral view from the right. Photos by A. Chichvarkhin. Рис. 3. Dendronotus frondosus, фотографии живых особей. A - W204, особь 16 мм длиной, вид с левой латеральной стороны. В - W205, особь 19 мм длиной, вид с правой латеральной стороны. Фотографии А. Чичвархина.

proaches are in congruence with our molecular phylogenetic study and thus, justify a separation status of specimens of Dendronotus sp. (W195W203, W206-W207) and also D. frondosus and $D$. kamchaticus findings in the Sea of Japan.

\section{Morphology}

We studied 24 Dendronotus specimens from three localities of northwestern Sea of Japan. The colouration patterns in each specimen were nearly similar and corresponded to the common colour of $D$. frondosus: variegated pattern with brown stripes and spots on the dorsal side of the body and upper parts of the foot (Figs. 3, 6, 9). However, 20 specimens also possess clearly visible stripes of white opaque pigment between rows of dorsolateral appendages (Fig. 9). Other external morphological features e.g. branching pattern of dorsolateral processes (Figs. 5A, 8A, 

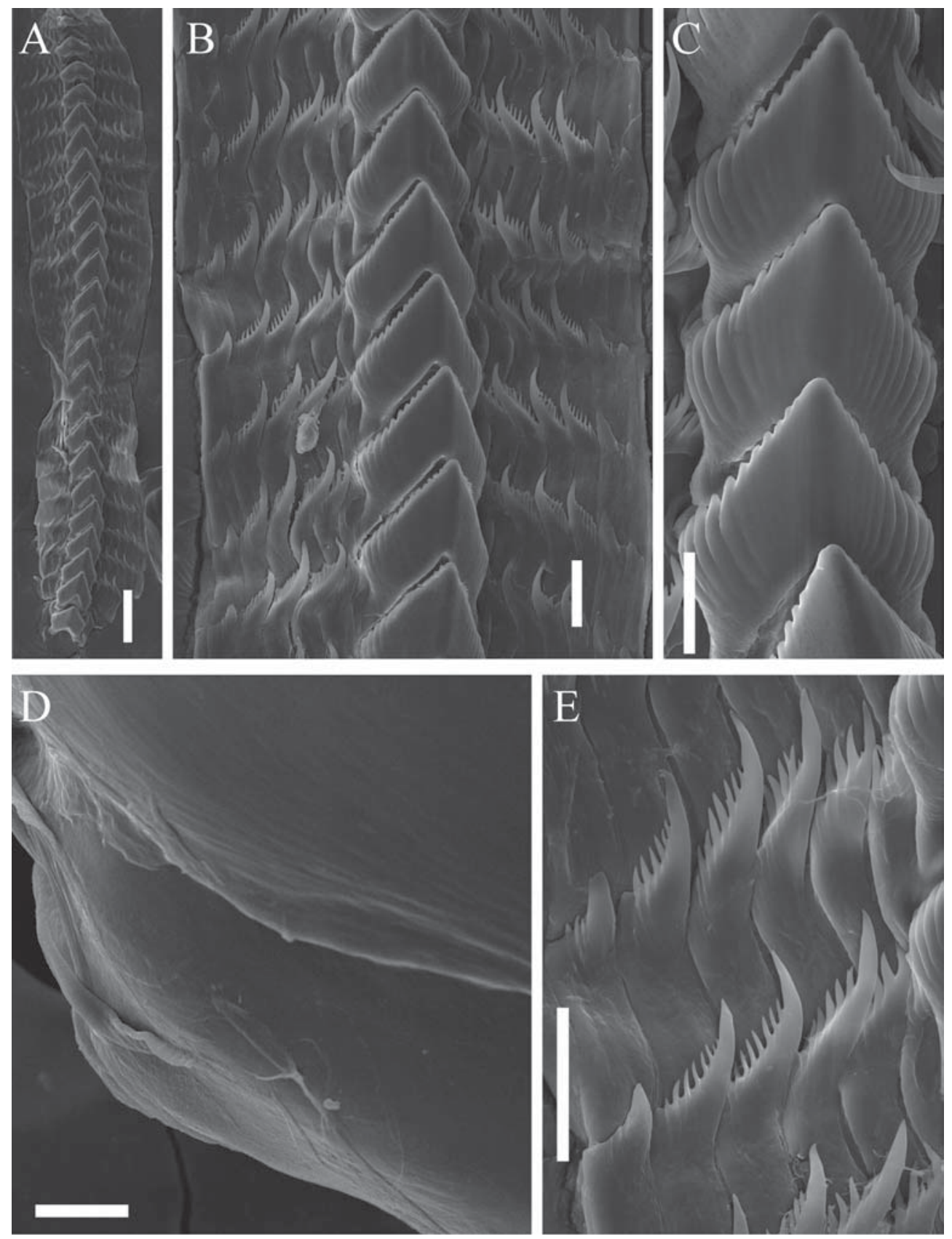

Fig. 4. Dendronotus frondosus, scanning electron micrographs of the radula and masticatory border of jaws. W205, specimen $21 \mathrm{~mm}$ in length. A - posterior part of the radula, main view; B - rachidian and lateral teeth; C - rachidian teeth; D - masticatory border of jaws, denticles are absent; E - lateral teeth. Scale bars: A $-100 \mu \mathrm{m}$; B, C, E $-20 \mu \mathrm{m} ; \mathrm{D}-30 \mu \mathrm{m}$.

Рис. 4. Dendronotus frondosus, микрофотографии участков радулы и жевательной поверхности челюстей (CЭM). W205, особь 21 мм длиной. A - задняя часть радулы, общий вид; В — центральные и латеральные зубы; С - центральные зубы; D - жевательная поверхность челюстей, зубчики отсутствуют; Е - латеральные зубы. Масштаб: А - 100 мкм; В, C, E - 20 мкм; D - 30 мкм. 

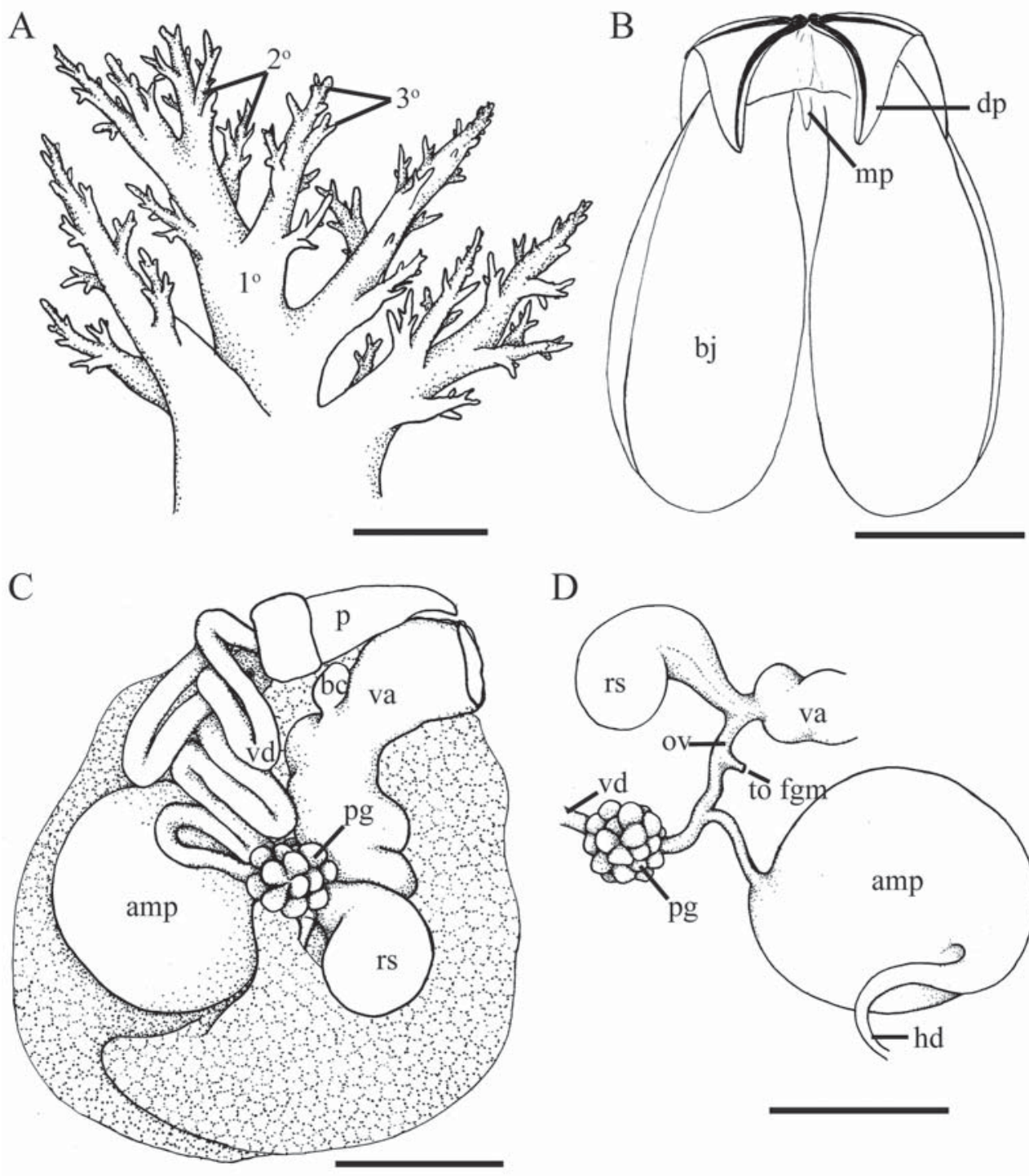

D

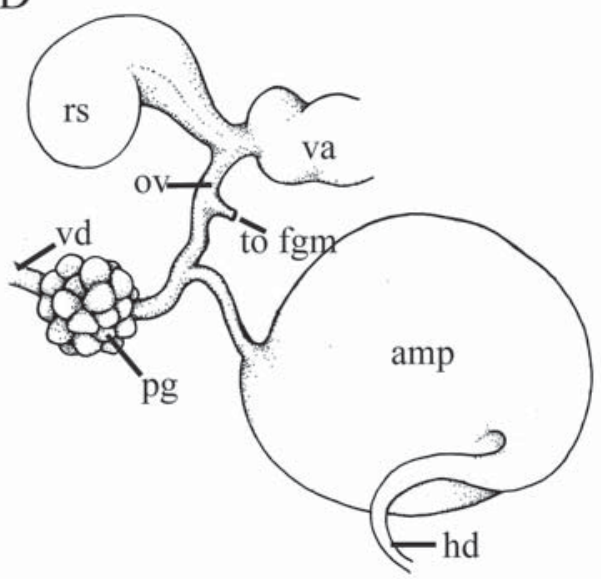

Fig. 5. Dendronotus frondosus, drawings of the external morphology and anatomy. A - dorsolateral appendages branching pattern; $\mathrm{B}$ - jaws; $\mathrm{C}$ - main view of reproductive system; $\mathrm{D}$ - reproductive system, detailed.

Abbreviations: $1^{\circ}$ - primary stalks; $2^{\circ}-$ secondary branches; $3^{\circ}$ - tertiary branches; amp - ampulla; bc - bursa copulatrix; bj — jaw body; $\mathrm{dp}$ - dorsal process of the jaw; fgm — female gland mass; hd — hermaphroditic duct; $\mathrm{mp}$ - masticatory process of the jaw; ov — oviduct; $\mathrm{p}$ — penis; $\mathrm{pg}$ — prostata; $\mathrm{rs}$ — receptaculum seminis; va — vagina; $\mathrm{vd}$ - vas deferens. Scale bars $1 \mathrm{~mm}$.

Рис. 5. Dendronotus frondosus, особенности внешней и внутренней морфологии. А - особенности ветвления дорсолатеральных отростков; В - челюсти; С - общий вид половой системы; D область овидукта, детализировано.

Обозначения: $1^{\circ}$ - первичные ветви; $2^{\circ}$ - вторичные веточки; $3^{\circ}-$ третичные веточки; amp — ампулла; $b c-$ копулятивная сумка; $\mathrm{bj}$ - тело челюстей; dp - дорсальный отросток челюстей; fgm - женские железы; $\mathrm{hd}$ гермафродитный проток; $\mathrm{mp}$ - жевательный отросток челюстей; ov - овидукт; $\mathrm{p}$ - пенис; $\mathrm{pg}$ - простата; rs - семяриемник; va - вагина; vd - семяпровод. Масштаб 1 мм. 

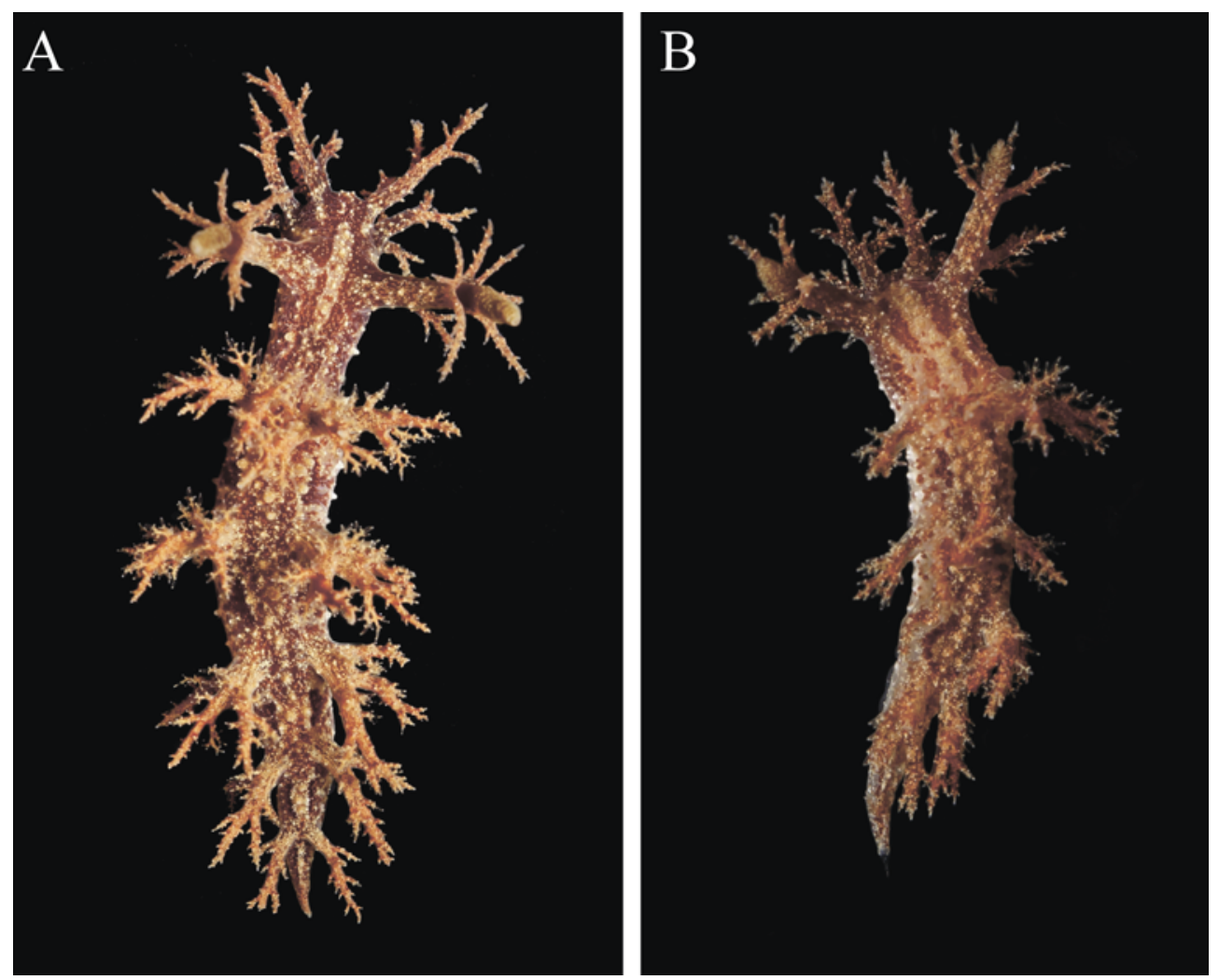

Fig. 6. Dendronotus kamchaticus, W194, living animals, dorsal view. A — specimen $18 \mathrm{~mm}$ in length; B specimen $11 \mathrm{~mm}$ in length. Photos by T. Antokhina.

Рис. 6. Dendronotus kamchaticus, W194, фотографии живых особей, вид с дорсальной стороны. А особь 18 мм длиной; В - особь 11 мм длиной. Фотографии Т. Антохиной.

11A), the number of veil papillae, the presence of lateral papillae, etc., were identical in all specimens studied. According to internal diagnostic characters, the most important and variable were the denticulation of masticatory border, radular morphology and the reproductive system morphology. Two specimens from Rudnaya Bay (W194) possess a smooth rachidian tooth (Fig. 7), which is a main diagnostic feature of D. kamchaticus, combining with variegated colour pattern. Other studied specimens have a highly denticulated rachidian tooth, with deep furrows on its surface (Figs. 4, 10). In two specimens collected in Amursky Bay (W204, W205) the smooth masticatory border of jaws was detected (Fig. 4D). This character is typical for $D$. frondosus. Meanwhile, masticatory border in other specimens possesses a single row of denticles (Fig. 10D). This feature has been described only for $D$. dalli, D. iris, D. regius, $D$. kalikal and D. venustus (Robilliard, 1970; Pola, Stout, 2008; Stout et al., 2010; Ekimova et al., 2015). The reproductive system morphology also well differs. Two specimens from Rudnaya Bay (W194) have an elongate sinuous ampulla, prostata consists of 7-8 oval alveoli and a narrow, elongate penis (Fig. 8C). These features correspond with original description of D. kamchaticus by Ekimova et al. (2015). Specimens W204, W205 from Amursky Bay possess very similar morphology of reproductive system to D. frondosus: wide semicircular ampulla, elongated penis and discoid prostate, which consists of 16-30 small alveolar glands. Finally, all other specimens show quite similar morphology of the reproductive system: an ampulla is wide 

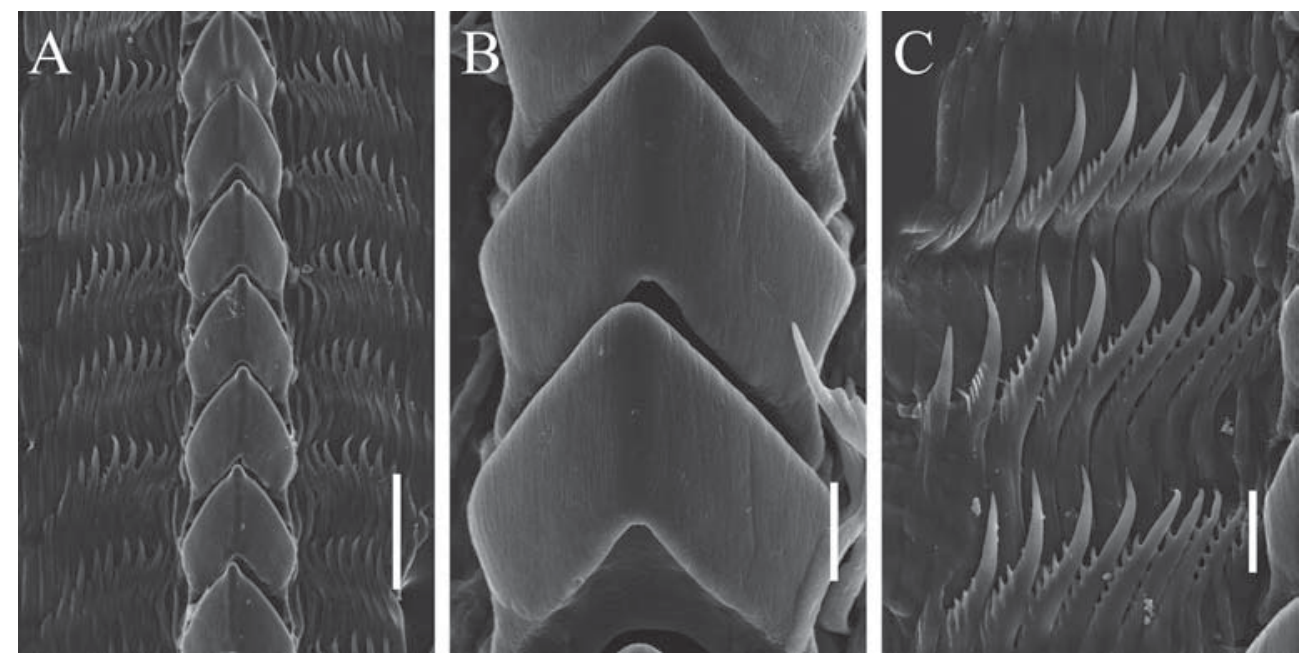

Fig. 7. Dendronotus kamchaticus, W194, scanning electron micrographs of the radula. A — rachidian and lateral teeth; B - rachidian teeth; C - lateral teeth. Scale bars: A $-100 \mu \mathrm{m} ; \mathrm{B}, \mathrm{C}-30 \mu \mathrm{m}$.

Рис. 7. Dendronotus kamchaticus, W194, микрофотографии участков радулы (СЭМ). А - центральные и латеральные зубы; В — центральный зуб; С — латеральные зубы. Масштаб: А — 100 мкм; В, $\mathrm{C}-30$ мкм.

and sinuous, prostate concentric ring-shaped, consists of 12-14 oval alveoli, penis is slightly curved. Such morphology of reproductive system has never been described for any other Dendronotus species. Therefore, our morphological data indicate the presence of at least three species in northwestern part of the Sea of Japan: D. frondosus, D. kamchaticus and Dendronotus sp. and thus are congruent with molecular phylogenetic analysis and molecular species delimitation analysis.

\section{Identification}

According to the results of morphological and molecular analyses, we can suggest that studied specimens with Voucher number W194 truly belong to species D. kamchaticus. Specimens with Voucher numbers W204 and W205 are highly similar in external and internal morphology with Atlantic and Arctic individuals of D. frondosus, this result is strongly supported by molecular analysis. Molecular analysis of Dendronotus sp. specimens (Voucher numbers W195-W203; W206-W207) showed their separation from other Dendronotus species avail- able for molecular study (Fig. 2). This species appears in the same clade as D. frondosus and $D$. venustus, which corresponds in some ways with diagnosis of $D$. primorjensis, according to its original description (Martynov et al., 2015). However, in this description it was stated that "molecular phylogenetic analysis of COI gene placed D. primorjensis at the base of the clade, which includes Atlantic species D. frondosus (Ascanius, 1774) and Pacific species D. venustus MacFarland, 1966, but as a separate branch, different from these two species" (Martynov et al., 2015). In contrast, in our both concatenated (Fig. 2) and single-gene COI trees, studied specimens do never possess a basal placement to $D$. frondosus and $D$. venustus. Unfortunately, the sequences of $D$. primorjensis type material have not been published by authors. The official request of these sequences was declined by corresponding author of that paper (A.V. Martynov). Type specimens of this species deposited in ZMMU (holotype Op-419 and paratype Op420) were not allowed for examination. Therefore, due to lack of reliable possibility of these species comparison, we can attribute only indirect evidences e.g. the placement of our speci- 


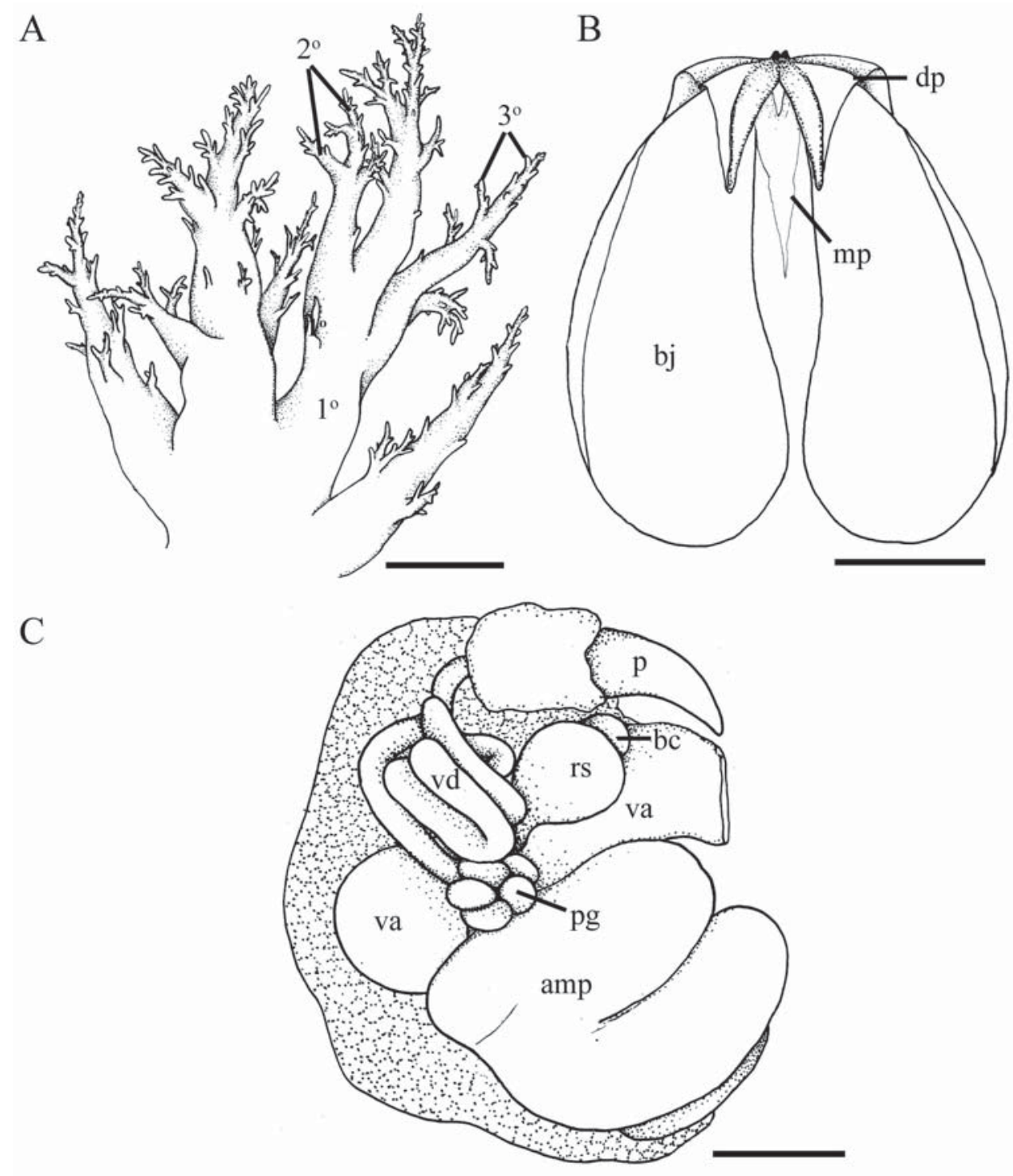

Fig. 8. Dendronotus kamchaticus, W194, drawings of the external morphology and anatomy. A dorsolateral appendages branching pattern; $\mathrm{B}$ - jaws; $\mathrm{C}$ - main view of reproductive system.

Abbreviations: $1^{\circ}-$ primary stalks; $2^{\circ}-$ secondary branches; $3^{\circ}-$ tertiary branches; amp - ampulla; bc - bursa copulatrix; bj - jaw body; dp - dorsal process of the jaw; $\mathrm{mp}$ - masticatory process of the jaw; $\mathrm{p}$ - penis; $\mathrm{pg}-$ prostata; rs - receptaculum seminis; va - vagina; vd — vas deferens. Scale bars $1 \mathrm{~mm}$.

Рис. 8. Dendronotus kamchaticus, W194, особенности внешней и внутренней морфологии. А особенности ветвления дорсолатеральных отростков; В — челюсти; С - общий вид половой системы. Обозначения: $1^{\circ}$ — первичные ветви; $2^{\circ}-$ вторичные веточки; $3^{\circ}-$ третичные веточки; amp — ампулла; $\mathrm{bc}-$ копулятивная сумка; $\mathrm{bj}$ - тело челюстей; $\mathrm{dp}$ - дорсальный отросток челюстей; $\mathrm{mp}$ - жевательный отросток челюстей; p - пенис; pg - простата; rs - семяприемник; va - вагина; vd - семяпровод. Масштаб 1 мм. 

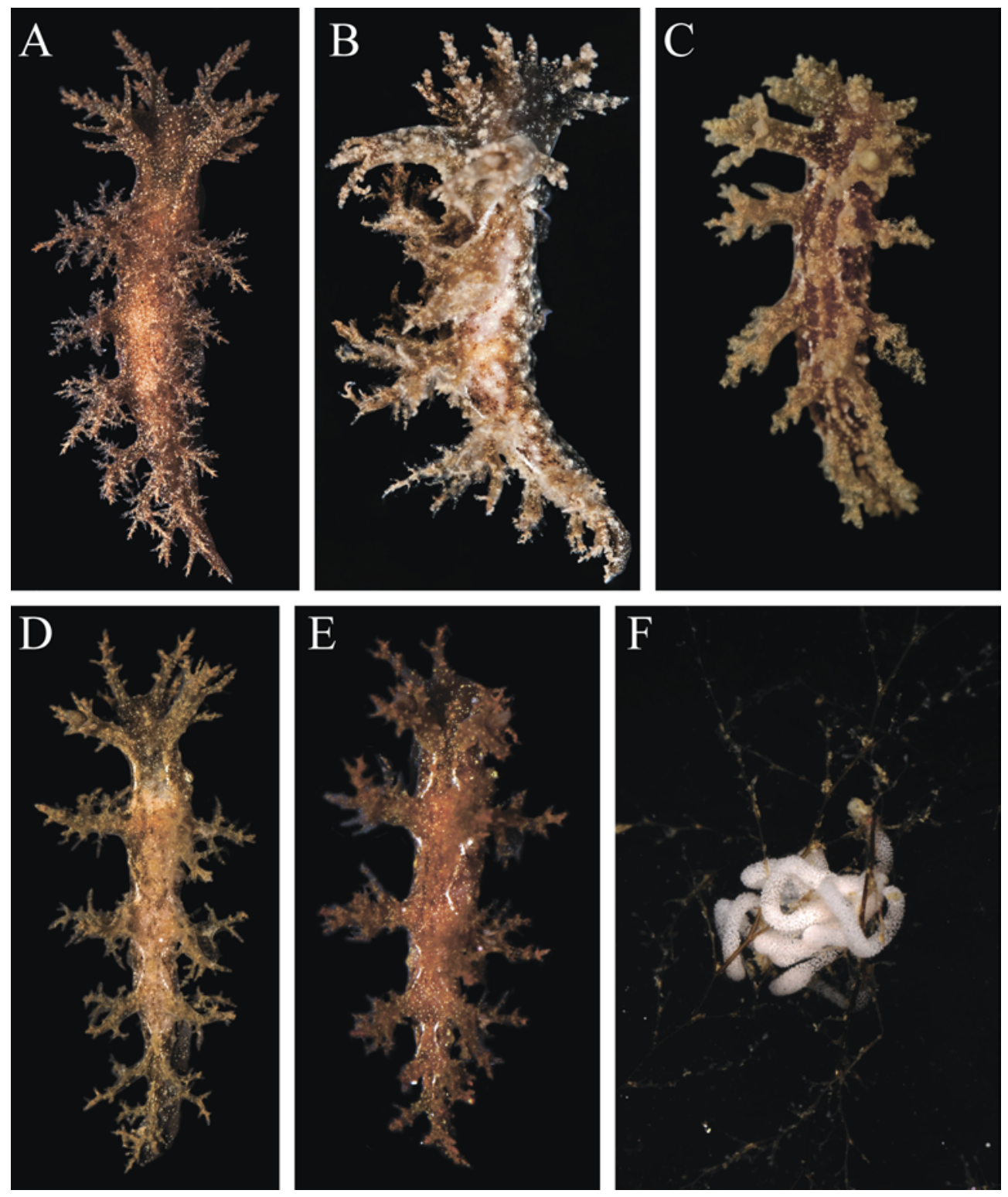

Fig. 9. Dendronotus dudkai sp.n., living animals and hatch. A - paratype ZMMU Lc-40366, specimen 21 mm in length; B - W201, specimen $12 \mathrm{~mm}$ in length; C — W198, specimen $8 \mathrm{~mm}$ in length; D — paratype ZMMU Lc-40367, specimen $28 \mathrm{~mm}$ in length; E — WS2894, specimen $24 \mathrm{~mm}$ in length; F — hatch on Obelia cf. longissima colony. Photos by A. Chichvarkhin.

Рис. 9. Dendronotus dudkai sp.n., фотографии живых особей и кладки. А — паратип ZMMU Lc-40366, особь 21 мм длиной; В - W201, особь 12 мм длиной; C — W198, особь 8 мм длиной; D — паратип ZMMU Lc-40367, особь 28 мм длиной; E — WS2894, особь 24 мм длиной; F — кладка на колонии Obelia cf. longissima. Фотографии А. Чичвархина. 
mens on the phylogenetic tree, which is contrary to original description of $D$. primorjensis.

Regarding external morphology, our specimens are clearly distinguished from $D$. primorjensis in colour pattern. In D. primorjensis description, authors stated that "according to external features, the new species differs from both $D$. frondosus and $D$. venustus by lack of large aggregations of white pigment". However, our specimens possess well-developed stripes of opaque white pigment on the dorsal side between cerata (Fig. 9). In D. frondosus, D. venustus, D. kamchaticus and D. kalikal (species with similar colour pattern) white and golden opaque pigment is placed only in low turbecles (Ekimova et al., 2015; present study). Moreover, in D. primorjensis this character is developed even less than in these species, according to the original description. In general, as it was said above, the description of $D$. primorjensis is very poor and provides mostly general information on external and internal morphology. Some important taxonomic morphological characters were not described at all. For example, the description of reproductive system is too general and containing only features that are similar in all Dendronotus species (form of the prostate, form of the penis, form of the vas deference and colouration of the hermaphroditic gland). Meanwhile the most important diagnostic characters were not described (form of ampulla, number of prostate lobules and position of bursa copulatrix). The description of the external morphology and radula can also refer to species $D$. frondosus, D. venustus, D. kalikal.

Based on the foregoing significant discrepancy between Dendronotus primorjensis description and our specimens' characters, and because of unavailability of $D$. primorjensis type material in referred museum collection, and its author's denial to provide them for detailed molecular and morphological study we suppose these specimens are lost if ever existed. Therefore, we are designating the name $D$. primorjensis as nomen dubium, and suggesting that our specimens of Dendronotus sp. belongs to a distinct species, new for science, and its description is provided below.

\section{Systematic descriptions}

Due to particular difficulty of distinguishing Dendronotus species from the northwestern part of the Sea of Japan we provide an extended systematic descriptions of all three species analyzed.

Nudibranchia Cuvier, 1817

Dendronotina Odhner, 1934

Family Dendronotidae Odhner, 1934

Dendronotus Alder et Hancock, 1845

Type species: Dendronotus frondosus (Ascanius, 1774), by original designation.

Dendronotus frondosus (Ascanius, 1774) Figs. 3-5. fig. 2.

Amphitrite frondosa Ascanius, 1774: 155-158, pl. 5,

See Robilliard (1970) and Ekimova et al. (2015) for a full list of synonyms

Material examined: W204, 1 specimen, Sea of Japan, Amursky Bay, near the Institute of Marine Biology, 2-5 m depth, coll. K. Dudka, 25 May 2014; W205, Sea of Japan, Amursky Bay, near the Institute of Marine Biology, 2-5 m depth, coll. K. Dudka, 25 May 2014.

Description: External morphology (Figs. 3, $5 \mathrm{~A})$. Body elongate, laterally compressed. Foot narrow, tail short. Oral veil with 10-14 short lip papillae and 4-5 secondary branched appendages. Rhinophoral sheaths with long stalk and five crown appendages. Lateral papilla moderate in size with small secondary branches. Rhinophores with 6-10 lamellae. 5 pairs of dorsolateral processes. Dorsolateral processes moderately branched by secondary and tertiary branches of similar size (Fig. 5A). Digestive gland diverticula penetrate dorsolateral processes and rhinophoral branched processes. These diverticula in first pair of cerata and rhinophores originate from anterior lobe of digestive gland; others arise from posterior lobe. Anal opening on right side of body about midway between first and second pair of dorsolateral processes. Reproductive openings lateral, below first pair of dorsolateral processes on right side. 
Colour (Fig. 3): Background colour usually white or light-pink. Brown spots, lines, stripes and dots placed on dorsal side of body und upper parts of foot. Body covered by opaque golden or white pigment on which placed in small tubercles or gathered in large spots. Digestive gland diverticula can be seen through transparent body wall, digestive gland brown. Rhinophores similar in colour to body.

Internal morphology (Figs. 4, 5B-D): Length of dorsal processes of jaws about one-third length of jaw body. Inclined posteriorly at about $30^{\circ}$. Masticatory process about one-fifth as long as jaw body, slightly curved downwards. Masticatory border without denticles (Fig. 4D). Masticatory process strong, dark at base, transparent and subulate posteriorly. Jaw body yellow, brown towards masticatory border and ligament. Radula formula: $33 \times 6-7.1 .6-7$ (W205). Rachidian tooth strong, triangular, approximately 1.2 times longer than width. Rachidian tooth bears 8-12 well-defined sharp denticles with large furrows on both sides of reduced cusp (Fig. 4B, C). Lateral teeth slightly curved towards midline and possess 5-10 large sharp denticles (Fig. 4E). Outermost lateral teeth flattened with two or three reduced denticles. Innermost laterals thin and highly denticulated. Reproductive system triaulic (Fig. 5C, D). Ovotestis consists of numerous white rounded lobules. Long hermaphroditic duct leads to wide semicircular ampulla. Prostate discoid body consists of 16-30 small alveolar glands. Distal part of vas deferens long and winding, expanding to elongate penis. Oviduct connects through insemination duct into female gland complex. Vagina long, gradually narrowing into a rounded seminal receptaculum, and then connecting into oviduct and female gland mass. Bursa copulatrix small and rounded. Female genital aperture opens posterior to penis on right side of body, between first and second pairs of dorsolateral processes.

Ecology: Depth range does not exceed $20 \mathrm{~m}$ (Ekimova et al., 2015; present study). Feeds on several tecaphoran hydrozoan species from genera Obelia, Dynamena, Gonothyraea, and Laomedea. Egg mass is narrow cord, forms an irregular, compressed off-white spiral. Reproduction period from June to October; the larva is a planctotrophic veliger with oval shell.

Distribution: North-West and North-East Atlantic, including the White and the Barents seas, north parts of the Sea of Japan

Dendronotus kamchaticus Ekimova, Korshunova, Schepetov, Neretina, Sanamyan et Martynov, 2015

Fig. 6-8.

Type material: Holotype ZMMU Op-245, northwest Pacific, Kamchatka, Avacha Bay, 7 m depth, coll. D.B. Semenov, 15 June 2010.

Material examined: W194, 2 specimens, Sea of Japan, Rudnaya Bay, 10-16 m depth, coll. T. Antokhina, A. Chichvarkhin, 8 May 2013.

Description. External morphology (Figs. 6, $8 \mathrm{~A})$ : Body elongate, laterally compressed. Foot narrow, tail short. Oral veil with 4-6 lip papillae and branched appendages. Primary stalks of veil appendages tall and slender, giving rise to numerous secondary branches with short tertiary branches. Rhinophoral sheath divide into 56 crown papillae that about same length. Lateral papillae (about one-third or one-half of sheath length) branches off sheath base and expanded with secondary branches. Rhinophores bear 1420 lamellae. 5 pairs of dorsolateral appendages. Primary stalks of cerata long, slender and conical (Fig. 8A). Secondary branches of dorsal appendages well-expressed, narrow; tertiary branches of dorsal appendages short, rounded at tip. Digestive gland diverticula penetrate cerata and rhinophoral branched processes. These diverticula in first part of cerata and rhinophores originate from anterior lobe of digestive gland; others arise from posterior lobe. Anal opening on right side of body about midway between first and second pair of dorsal appendages. Reproductive openings lateral near the first pair of cerata on right side.

Colour (Fig. 6): Background colour is transparent white, with complex pattern of light, dark, and red-brown spots and stripes. On dorsal side spots and stripes merge and form char- 
acteristic striped pattern. Lateral sides of body devoid of stripes but covered with brown spots. Brown branches of digestive gland clearly visible through thin walls of rhinophoral sheathes, dorsal appendages, and velar papillae. Lamellae of rhinophores brown. All body, including rhinophoral sheathes, cerata, and upper parts of foot covered with white and golden pigment spots. Large dots of pigment are often placed inside tubercles on dorsal and lateral surface of body.

Internal morphology (Figs. 7, 8B, C): Dorsal process of jaws strong; length about onequarter of jaw body length. Inclined posteriorly at about $15^{\circ}$. Length of dorsal processes of jaws about one-third length of jaw body, strong at base, but becoming transparent and subulate posteriorly. Denticles absent on masticatory border. Radula formula: $24 \times 9-10.1 .9-10$ (adult specimen), $17 \times 10-11.1 .10-11$ (subadult specimen). Rachidian tooth large and strong, with quadrangular base and triangular cusp. Rachidian tooth of subadult specimens bear 10-12 small, relatively sharp denticles that continue down dorsal side of cusp as thin furrows. In adult specimens denticles absent, tooth completely smooth, sometimes with faint furrows (Fig. 7A, B). Colour of oldest rachidian teeth is light yellow, others transparent. 9-11 lateral teeth, each consisting of elongate, flattened plate and cusp. Outer border of cusps bear 5-9 sharp and strong denticles. Innermost lateral tooth thin, delicate, and highly denticulated, one or two outermost teeth narrow, thin and flattened and do not bear denticles (Fig. 7C). Reproductive system triaulic (Fig. 8C). Large white ovotestis composed of many rounded lobules, and leading to hermaphrodite duct that expands into elongate sinuous ampulla. Prostata consists of 7-8 oval alveoli, distal part of vas deferens narrow and winding, expanding to narrow, elongate unarmed penis. Oviduct connects through insemination duct into female gland complex. Vagina long, strait, with small bursa copulatrix, gradually narrows into rounded seminal receptaculum. Long insemination duct emerges from seminal receptaculum and connects into oviduct and female gland mass. Female genital aperture opens posterior to penis on right side of body, between first and second pairs of dorsolateral processes.

Ecology: Found subtidally at $7-16 \mathrm{~m}$ in depth. Inhabits brown and red algae or rocks covered with hydrozoan colonies (Thecaphora). Egg masses are unknown.

Distribution: This far, known from Avacha Bay, Kamchatka peninsula (Ekimova et al., 2015) and from Rudnaya Bay, Sea of Japan (present study).

Remarks: D. kamchaticus was described from Avacha Bay (North-West Pacific, Kamchatka peninsula) at the depth 7-10 m (Ekimova et al., 2015). Here for the first time this species out of its type locality is described. External and internal morphology of holotype corresponds to our specimens, with a few exceptions. Type specimens of $D$. kamchaticus are defined by small dorsolateral appendages with short and bulbous primary stalks and small secondary branches and lacking tertiary. Probably it can be related with preserving changes of soft tissues. Radula formula described in Ekimova et al. (2015) is $16-20 \times 7-10.1 .7-10$, while in our specimens it is $17-24 \times 9-11.1 .9-11$. However, it can be explained as intraspecific variations of radular teeth number. Morphology of the rachidian and lateral teeth, jaws and reproductive system is quite similar in type specimens and individuals studied.

It can be concluded that our specimens truly belong to D. kamchaticus according to both morphological and molecular analyses. The first finding of this species in the Sea of Japan extends its known distribution from the boreal regions of Northwestern Pacific to the northern part of the Sea of Japan. Supposedly, this species can be also found in Sakhalin, Kuril Islands and in the Okhotsk Sea.

\section{Dendronotus dudkai sp.n.}

Figs. 9-11.

Dendronotus frondosus sensu Baba, 1993 non Ascanius, 1774

Type material: Holotype: ZMMU Lc-40364, Sea of Japan, Vostok Bay, Vostok Marine Biological Station, 6-7 m depth, coll. A. Chich- 

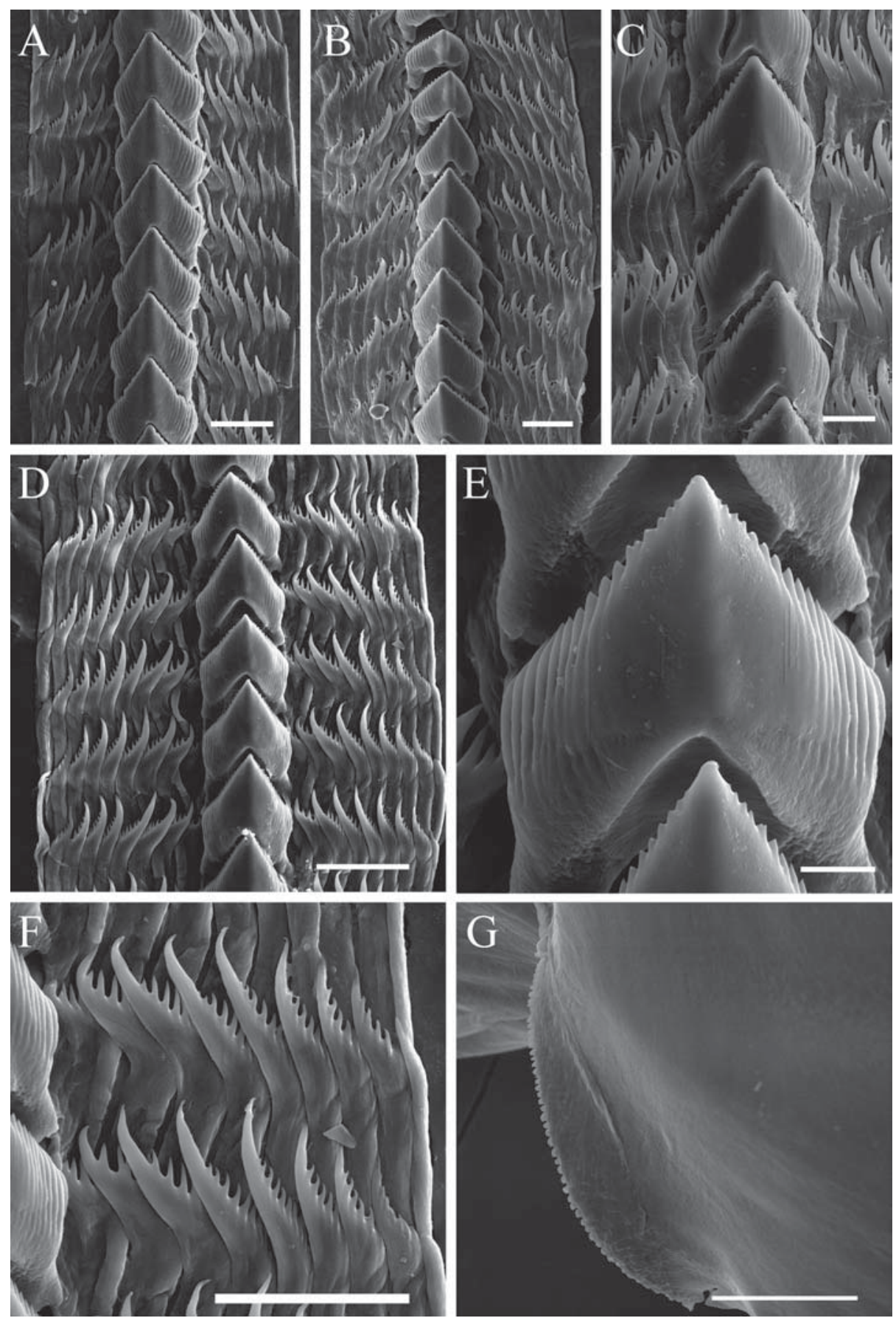

Fig. 10. Dendronotus dudkai sp.n., scanning electron micrographs of the radula and masticatory process of jaws. A - W201, rachidian and lateral teeth; B - W203, rachidian and lateral teeth; C - W202, rachidian and innermost lateral teeth, D - W197, rachidian and lateral teeth; E - W197, rachidian tooth; F — W197, lateral teeth; $\mathrm{G}$ - masticatory process of jaws, masticatory border with a single row of denticles. Scale bars: $\mathrm{A}, \mathrm{B}, \mathrm{F}-50 \mu \mathrm{m} ; \mathrm{C}-20 \mu \mathrm{m} ; \mathrm{D}-80 \mu \mathrm{m} ; \mathrm{E}-10 \mu \mathrm{m} ; \mathrm{G}-100 \mu \mathrm{m}$. 
varkhin \& A. Goloseyev, 10-15 August 2014. Paratypes: ZMMU Lc-40365, 1 specimen, Sea of Japan, Vostok Bay, Vostok Marine Biological Station, 6-7 m depth, coll. A. Chichvarkhin \& A. Goloseyev, 15 August 2014; ZMMU Lc40366, 1 specimen, Sea of Japan, Amursky Bay, near the Institute of Marine Biology, 2-5 m depth, coll. K. Dudka, 25 May 2014; ZMMU Lc-40367, 2 specimens, Sea of Japan, Vostok Bay, Vostok Marine Biological Station, 10-15 $\mathrm{m}$ depth, coll. I. Ekimova \& A. Chichvarkhin, 10-15 September 2015.

Additional material examined: W195, 1 specimen, Sea of Japan, Rudnaya Bay, 10 m depth, coll. A. Chichvarkhin, 10 June 2012; W196, 1 specimen, Sea of Japan, Rudnaya Bay, 10-12 m depth, coll. A. Chichvarkhin, 8 June 2013; W197-W200, 4 specimens, place, depth, date and collectors are the same as W196; W201, 1 specimen, Sea of Japan, Vostok Bay, Vostok Marine Biological Station, 6-7 m depth, coll. A. Chichvarkhin \& A. Goloseyev, 10 August 2014; W202, 2 specimens, Sea of Japan, Vostok Bay, Vostok Marine Biological Station, 6-7 m depth, coll. A. Chichvarkhin \& A. Goloseyev, $15 \mathrm{Au}-$ gust 2014; W207, 3 specimens, Sea of Japan, Vostok Bay, Vostok Marine Biological Station, 6-7 m depth, coll. K. Dudka, 15 March 2015; WS2894-WS2897, 4 specimens, Sea of Japan, Vostok Bay, Vostok Marine Biological Station, 10-15 m depth, coll. I. Ekimova \& A. Chichvarkhin, 10-15 September 2015.

Type locality: Sea of Japan, Vostok Bay, Vostok Marine Biological Station, 6-7 m depth, on Obelia cf. longissima (Pallas, 1766).

Etymology: Dedicated to our friend and invaluable assistant Mr. Konstantin Dudka, stuff diver of Institute of Marine Biology RAS (Vladivostok), one of the first collectors of this species.

Description. External morphology (Figs. 9, 11A): Body elongate, laterally compressed. Foot narrow, tail short. Oral veil small with 6-12 large, secondary branched cerata. Muscular lips with 5-10 short lip papillae. Rhinophoral sheaths with long stalk and 4-5 crown secondary branched appendages. Lateral papillae moderate in size with small secondary branches. Rhinophores with 8-10 lamellae. 6-8 pairs of highly branched dorsolateral processes, size and degree of branching decrease towards the tail. 2-5 primary stalks on each cerata, branching pattern "rosette" (Fig. 11A). Secondary branches long and rounded, tertiary branches short and sometimes pointed. Digestive gland diverticula penetrate cerata and rhinophoral sheath processes. These diverticula in first pair of cerata and rhinophores originate from anterior lobe of digestive gland; others arise from posterior lobe. Cardiac prominence slightly raised. Body covered with conical papillae that usually tallest on cardiac prominence. Anal opening on right side of body about midway between first and second pair of dorsolateral processes. Reproductive openings lateral, below first pair of dorsolateral processes on right side.

Colour (Fig. 9): General colour pattern varies from beige to dark-brown. Background colour translucent-white or light yellow. A lot of spots, stripes and dots on dorsal side of the body, cerata, rhinophoral sheath processes and upper parts of foot. Their colour varies from yellow to dark-brown. Some specimens covered with dots of golden or white opaque pigment. This pigment locates also in low body papillae and small turbecles. All specimens possess well-visible white stripes between pairs of cerata. Digestive gland diverticula can be seen through transparent body wall. Digestive gland beige or brown. The colour of the rhinophores similar to body colour.

Internal morphology (Figs. 10, 11B-D): Dorsal processes of jaws about 2.5 times shorter

Рис. 10. Dendronotus dudkai sp.n., микрофотографии участков радулы и жевательной поверхности челюстей (СЭМ). A - W201, центральные и латеральные зубы; В - W203, центральные и латеральные зубы; C - W202, центральные и внутренние латеральные зубы, D - W197, центральные и латеральные зубы; E - W197, центральный зуб; F - W197, латеральные зубы; G жевательный отросток челюстей, жевательная поверхность несет одинарный ряд зубчиков. Масштаб: A, B, F - 50 мкм; C - 20 мкм; D - 80 мкм; E - 10 мкм; G - 100 мкм. 

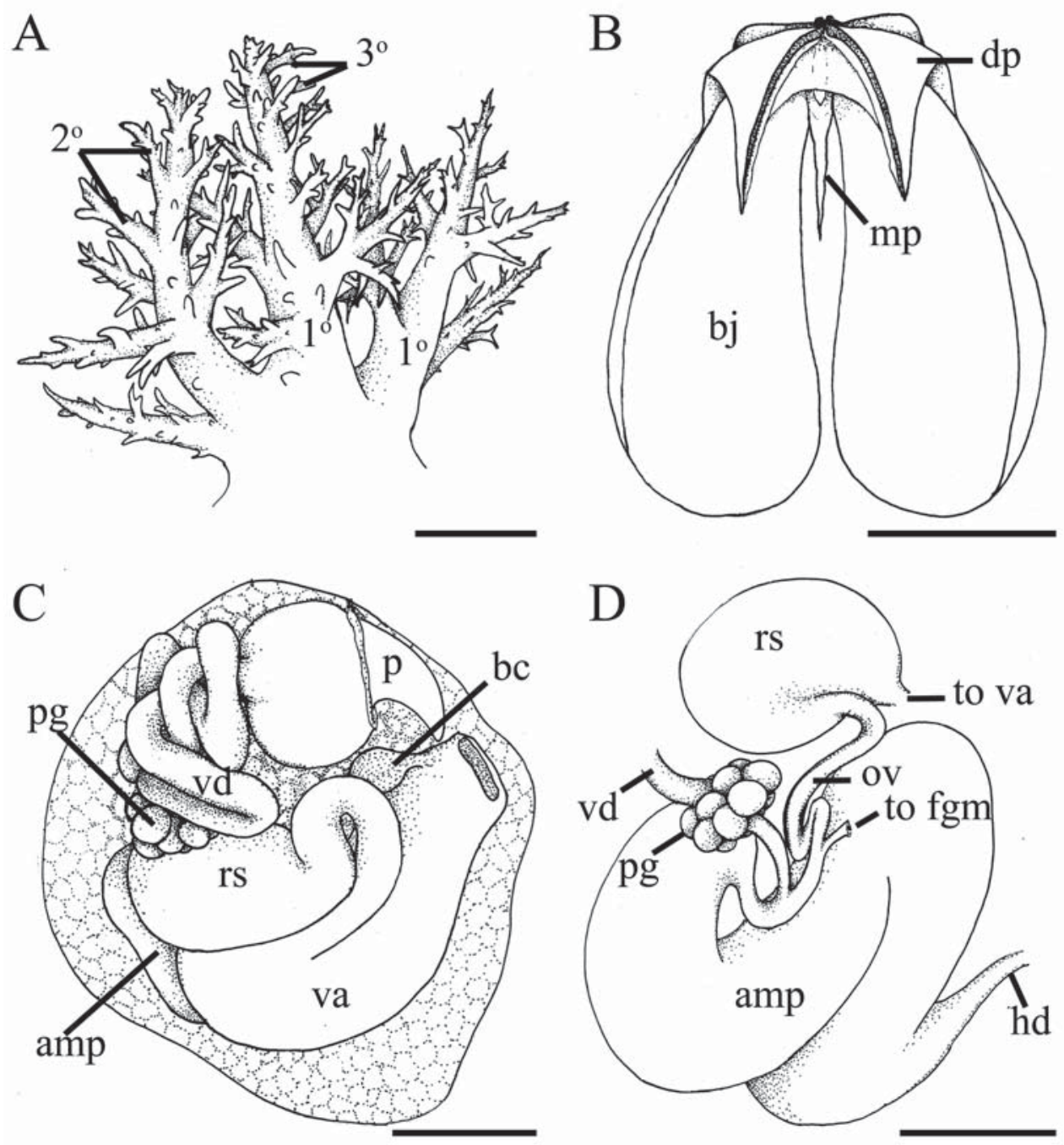

Fig. 11. Dendronotus dudkai sp.n., drawings of the external morphology and anatomy. A - dorsolateral appendages branching pattern; $\mathrm{B}$ - jaws; $\mathrm{C}$ - main view of reproductive system; $\mathrm{D}$ - reproductive system, detailed.

Abbreviations: $1^{\circ}$ - primary stalks; $2^{\circ}$ - secondary branches; $3^{\circ}$ — tertiary branches; amp — ampulla; bc — bursa copulatrix; bj — jaw body; dp — dorsal process of the jaw; fgm — female gland mass; hd — hermaphroditic duct; mp — masticatory process of the jaw; ov — oviduct; $p$ - penis; pg — prostata; rs — receptaculum seminis; va — vagina; vd - vas deferens. Scale bars $1 \mathrm{~mm}$.

Рис. 11. Dendronotus dudkai sp.n., особенности внешней и внутренней морфологии. А- особенности ветвления дорсолатеральных отростков; В — челюсти; С - общий вид половой системы; D область овидукта, детализировано.

Обозначения: $1^{\circ}$ — первичные ветви; $2^{\circ}$ - вторичные веточки; $3^{\circ}$ - третичные веточки; amp — ампулла; $b c-$ копулятивная сумка; $\mathrm{bj}$ - тело челюстей; dp — дорсальный отросток челюстей; fgm - женские железы; hd гермафродитный проток; $\mathrm{mp}$ - жевательный отросток челюстей; ov — овидукт; $\mathrm{p}$ - пенис; $\mathrm{pg}$ - простата; $\mathrm{rs}$ семяприемник; va - вагина; vd - семяпровод. Масштаб 1 мм. 
than jaw body (Fig. 11B). Inclined posteriorly at about $45^{\circ}$. Masticatory process about one-third as long as jaw body, slightly curved at base and become transparent and subulate posteriorly. Masticatory border with a single raw of denticles (Fig. 10G). Radula formula: $32 \times 7-8.1 .7-$ 8 (W203); $27 \times 6-7.1 .6-7$ (W201), $29 \times 8$ 9.1.8-9 (W196) (Fig. 10A-D). Rachidian tooth strong, triangular, length same as width, bears 12-18 sharp denticles with thin furrows on both sides of the reduced cusp (Fig. 10E). Lateral teeth slightly curved toward midline, bear 4-8 well-defined denticles (Fig. 10F). Outermost lateral teeth form varies from flattened shape to narrow with pointed apex. Innermost lateral teeth thin and highly denticulated. Reproductive system triaulic (Fig. 11C, D). Ovotestis large and white, composed from number of rounded lobules, leads to hermaphrodite duct. Ampulla wide and sinuous, merging with oviduct and connecting into prostate. Prostate concentric ring-shaped, consists of 12-14 oval alveolar glands. Distal part of vas deference winding expand into wide, muscular portion. Penis slightly curved, lacking armature. Oviduct connects through insemination duct into female gland complex. Vagina long, convoluted, narrows into rounded seminal receptaculum and then connects into oviduct and female gland mass. Small bursa copulatrix near proximal part of vagina, Female genital aperture opens posterior to penis on right side of body, between first and second pairs of dorsolateral processes.

Ecology: Found subtidally at $2-16 \mathrm{~m}$ in depth. Feeds on tecaphoran hydrozoan colonies of the family Campanulariidae (Obelia cf. longissima). These colonies occupied artificial substrates (ropes) only; we never found them with Dendronotus spp. on natural substrates. Reproduction period in June-July. Egg mass is narrow white cord, coiled on hydrozoan colonies.

Distribution: the Sea of Japan: from Rudnaya Bay to Amursky Bay, Sado Isl. Probably has wider distribution.

Remarks:

The differences between $D$. dudkai sp.n. and $D$. primorjensis were discussed above. The individuals of $D$. dudkai sp.n. have very similar internal and external morphology with eastern Pacific species $D$. venustus and amphiboreal $D$. frondosus. Nevertheless, an array of diagnostic differences can be designated in these three species. In contrast with $D$. dudkai sp.n., $D$. venustus possesses unbranched papillae of rhinophoral sheath, very large outgrowth of cardiac prominence, the ampulla is crescent-shaped. $D$. frondosus is distinguished from $D$. dudkai sp.n. by absence of denticles on the masticatory process of jaws, elongated shape of rachidian teeth, flattened shape of outer lateral teeth with no cusp; the ampulla $D$. frondosus is rounded, prostate contains more alveoli (16-40). According to morphological cladistic analysis by Stout et al. (2010), morphological differences shown above are sufficient for species delimitation.

Similar colour pattern and morphology is specific also to D. kamchaticus, D. kalikal as well as some colour variations of $D$. lacteus. Nevertheless these species differ from $D$. $d u d$ kai sp.n. in radular morphology. The rachidian tooth in D. kamchaticus is smooth, denticles and furrows are absent. D. kalikal possesses elongated rachidian tooth bearing tiny denticles along external edge, although the number of denticles is lower while furrows are very fine and nearly invisible. Rachidian tooth in D. lacteus possesses large number of small denticles, their furrows are fine, lateral teeth are triangle shaped with small proximal denticles; some individuals are lacking denticles.

The rachidian tooth of $D$. dudkai sp.n. radula possesses well-developed denticles that lengthen with deep furrows; conical cusp is reduced. This pattern of features distinguishes this species from $D$. dalli, D. kamchaticus, $D$. niveus (possessing smooth rachidian tooth), $D$. robustus, D. patricki, D. iris (developed conical cusp), D. rufus, D. lacteus, D. kalikal, D. albus, $D$. gracilis (denticle furrows more or less reduced till complete disappearance), D. subramosus (sporadic denticles and furrows), D. albopunctatus (furrows approach central part of the teeth). Teeth shape in D. dudkai sp.n. is well distinguished form $D$. noachi and D. regius spacing between margins in these two species increases toward the cusp. Rachidian tooth in $D$. 
dudkai sp.n. is similar to $D$. venustus, $D$. frondosus, D. comteti, D. orientalis. As said above, both $D$. frondosus and $D$. venustus differ from D. dudkai sp.n. with the features of internal and external morphology. D. comteti possesses elongated rachidian tooth and lower number of lateral ones (4-5). Besides that, this species possesses lower number of dorsolateral appendages (2-4 pairs), with no secondary branching. The number of lateral teeth in D. orientalis (2) is a good diagnostic trait to be distinguished from $D$. dudkai sp.n.

\section{Discussion}

As this had been considered earlier, the most common species $D$. frondosus possesses a wide amphiboreal distribution (Robilliard, 1970; Roginskaya, 1987; Baba, 1993). Confirmed southern borders of its distribution range were Cope Cod on the eastern US coast (Lemche, 1948), Californian shore, Bay of Biscay in France, and Sado Island in the Sea of Japan (Baba, 1993). However, in 2010, cladistics and molecular phylogenetic analysis confirmed the validity of $D$. venustus (Stout et al., 2010), a sister species of $D$. frondosus previously considered as its minor synonym. Further in 2015, two new species $D$. kalikal and D. kamchaticus were described from the Pacific shore of Kamchatka (Avacha Bay) (Ekimova et al., 2015). Both species possess similar to D. frondosus colouration but fundamentally different morphologies of the radula and the reproductive system. Considering these data, an exclusively amphiatlantic distribution is characteristic for 'amphiboreal' $D$. frondosus is presumed.

Due to the recent studies on the genus Dendronotus taxonomy, populations of the Sea of Japan represent key forms that may shed light on the global distribution range of $D$. frondosus. In this study, it has been shown that at least three Dendronotus species possessing similar external morphology to $D$. frondosus occur in northwestern part of this sea. These species are characterized with significant differences in radula, jaws, and reproductive system morphology. Molecular phylogenetic analysis of three mark- ers had also clearly discriminated these species by the means of ABGD analysis and GMYC method. These results are congruent with morphological data, single-gene and concatenated phylogenetic trees.

Discovery of D. kamchaticus in Rudnaya Bay of the Sea of Japan extends our knowledge on this species distribution in western Pacific. Two specimens from the Sea of Japan are identical with D. kamchaticus types from Kamchatka in either their internal morphology or according to molecular phylogenetic analysis of three gene markers. Nevertheless, the dorsolateral processes branching pattern, one of key speciesspecific characteristics, differs in both populations. Firstly, this is because different ontogenetic stages were used in the description and this study, as well as cerata morphology may be altered in preserved specimens. New data on $D$. kamchaticus populations may confirm a wider distribution of this species ranged to the northwestern Pacific including the Sea of Okhotsk, Commander, Kurile, Sakhalin Islands, northern Japan and Korea.

D. dudkai sp.n. had been recorded in three locations of the Sea of Japan: Rudnaya Bay, Vostok Bay and Amursky Bay. All specimens from these locations coincide in their internal and external morphology possessing good discriminative characters from the other species of the genus, as discussed above. Molecular phylogenetic analysis also confirmed discriminative morphological traits. Thus, our results confirm $D$. dudkai sp.n. validity.

Two D. frondosus specimens were found in Amursky Bay. Their morphology and molecular markers are identical or quite similar to Atlantic populations of $D$. frondosus. This finding impugns our recent conclusion about exclusively amphiatlantic distribution of this species (Ekimova et al., 2015). Baba (1993) recorded D. frondosus from Sado Island. He pointed out the denticles on the masticatory process of the jaw, while this trait is characteristic of $D$. dudkai sp.n., not $D$. frondosus as noted above. Therefore, the presumable distribution area of $D$. dudkai sp.n. includes the entire Sea of Japan, while our finding of $D$. frondosus in Amursky 
Bay is the only confirmed record of this species in northwestern Pacific. D. dudkai sp.n. may also be distributed outside the waters of the Sea of Japan in south Kuriles and Hokkaido islands. Opisthobranch fauna of Rudnaya Bay, where this species was recorded, has many common species with Kunashir Island and Shiretoko Peninsula due to local currents pattern (Chichvarkhin et al., 2015, 2016).

According to morphological and molecular phylogenetic analyses, D. frondosus and $D$. dudkai sp.n. are closely related sister species, although they are clearly distinguished with genetic characters. However, due to our data, it can be supposed that $D$. dudkai sp.n. and $D$. frondosus are sympatric sister species that feed on hydroid cnidarians of the family Campanulariidae. Possessing very consimilar pattern of morphological traits, though being clearly delimitated genetically, these species might possess distinct ecological traits. Indeed, immature individuals of $D$. frondosus were found in May when climatic conditions on Amursky Bay were similar to summer temperatures in the boreal and Arctic seas of the Atlantic (e.g. in the White and the Barents seas) while mature individuals of $D$. dudkai sp.n. appear in the end of June when water approaches a higher temperatures of ca. $20{ }^{\circ} \mathrm{C}$. Probably, D. frondosus is an amphiboreal species with disjunctive distribution area in Arctic seas while D. dudkai sp.n. is a west-Pacific sub-boreal species, and northwestern part of the Sea of Japan is an area of secondary sympatry of both species. This hypothesis may be supported with the fact of recent $D$. frondosus finding being found on the Alaska coast (according to molecular data provided by Ángel Valdés \& Tabitha Lindsay, California State Polytechnic University, Pomona, pers. comm.), although the other sister species $D$. venustus is known from the northeastern Pacific coasts that lie to the south of Alaska. The second hypothesis is $D$. frondosus being nevertheless an amphiatlantic species, while it occurs in the Sea of Japan due to anthropogenic invasion being delivered there with ballast waters of ships. This may be explained by single finding of this species in Amursky Bay located in Vladi- vostok, one of the major international ports in the area.

Due to similarities in external morphological features, the identification of Dendronotus species in the North-West part of the Sea of Japan may be a problematic point. The best way to distinguish specimens with a variegated colouration pattern from the Sea of Japan is to use a molecular analysis. However, it is rather expensive, complicated, taking considerable time and therefore not very useful for practical purposes. Therefore, the possibility of the species designation using morphological features becomes more sensible. On the one side, the colouration could be a good diagnostic character for identification of D. dudkai sp.n.: all studied specimens possess stripes of white opaque pigment on the dorsal side between the raws of appendages. Therefore, we propose to designate every specimen from the Sea of Japan with similar colouration as D. dudkai sp.n. The other good taxonomic characters are the radula morphology and masticatory process denticulation. D. kamchaticus could be easily identified by smooth rachidian tooth of radula, while in $D$. frondosus and D. dudkai sp.n. the tooth possesses a lot of denticles with deep furrows, which are clearly visible even under a simple microscope. Finally, features of masticatory border can distinguish $D$. frondosus and $D$. dudkai sp.n.: in $D$. frondosus it is smooth, while in $D$. dudkai sp.n. it possess a single raw of denticles.

\section{ACKNOWLEDGMENTS}

We are very grateful to all individuals who helped collect specimens, especially to K. Dudka, T. Antokhina, A. Goloseyev. G.N. Davidovich, A.G. Bogdanov, the staff of the scanning electron microscopic laboratory of the Moscow State University and the staff of Cooperative Far Eastern Center of Electron Microscopy are thanked for providing SEM facilities. I.A. Ekimova especially thanks A.V. Martynov for useful advices, comments, help and also for giving a deep knowledge on the nudibranch mollusc taxonomy at the beginning of the work. We are grateful to Ángel Valdés and Tabitha Lindsay for advices and providing a new data on Den- 
dronotus composition in the NE Pacific. We specially thank Diego Fontaneto for help with molecular species delimitation analyses. Material collection and SEM studies were supported by the Russian Science Foundation (grant 1450-00034). Molecular analysis was supported by the Russian Foundation for Basic Research (grant \#16-34-00955 mol_a).

\section{References}

Ascanius P. 1774. Beskrivelse over en Norske sneppe og et sodyr // Det Kong. Norske Vidensk. Selsk. Skrifter, Trondhjem. Vol. 5. P.153-158.

Baba K. 1993. A northern species of Dendronotus (Mollusca: Nudibranchia: Dendronotidae) from Sado Island, Sea of Japan // Report of the Sado Marine Biological Station, Niigata University. Vol.23. P.29-33.

Barco A., Houart R., Bonomolo G., Crocetta F., Oliverio M. 2013. Molecular data reveal cryptic lineages within the northeastern Atlantic and Mediterranean small mussel drills of the Ocinebrina edwardsii complex (Mollusca: Gastropoda: Muricidae) // Zoological Journal of the Linnean Society. Vol.169. P.389-407.

Behrens D.W. 1980. Pacific coast nudibranchs, a guide to the Opisthobranchs of the northeastern Pacific. Sea Challengers, Los Osos, CA. 112 p.

Behrens D.W. 1991. Pacific coast nudibranchs: a guide to the Opisthobranchs, Alaska to Baja California, 2nd edn. Monterey, CA: Sea Challengers. 107 p.

Cámara S., Carmona L., Cella K., Ekimova I., Martynov A., Cervera J.L. 2014. Tergipes tergipes (Förskal. 1775) (Gastropoda: Nudibranchia) is an amphiatlantic species // Journal of Molluscan Studies. Vol.80. No.5. P.642-646.

Carmona L., Bhave V., Salunkhe R., Pola M., Gosliner T.M., Cervera J.L. 2014a. Systematic review of Anteaeolidiella (Mollusca, Nudibranchia, Aeolidiidae) based on morphological and molecular data, with a description of three new species // Zoological Journal of the Linnean Society. Vol.171. P.108-132.

Carmona L., Lei B.R., Pola M., Gosliner T.M., Valdés A., Cervera J.L. 2014b. Untangling the Spurilla neapolitana (Delle Chiaje, 1841) species complex: A review of the genus Spurilla Bergh, 1864 (Mollusca: Nudibranchia: Aeolidiidae) // Zoological Journal of the Linnean Society. Vol.170. P.132-154.

Carmona L., Pola M., Gosliner T.M., Cervera J.L. 2013. A Tale that morphology fails to tell: a molecular phylogeny of Aeolidiidae (Aeolidida, Nudibranchia, Gastropoda) // PLoS ONE. Vol.8. P.e63000.

Chernyshev A.V. 2014. Opisthobranch mollusks (Gastropoda: Opisthobranchia) of cooling system of the Vladivostok Thermal Power Station $2 / /$ The Bulletin of the Russian Far East Malacological Society. Vol.18. P.89-96.
Chichvarkhin A.Yu., Chichvarkhina O.V., Chernyshev A.V. 2015. Runcinida valentinae Chernyshev, 2006 (Opisthobranchia: Runcinacea), a new Opisthobranch species for the Sea of Japan // Russian Journal of Marine Biology. Vol.41. No.3. P.214-218.

Chichvarkhin A.Yu., Chichvarkhina O.V., Kartavtsev Yu.P. 2016. Janolus fuscus O’Donoghue, 1924 (Gastropoda, Proctonotidae) - a species belonging to new nudibranch family of Russian marine fauna // Russian Journal of Marine Biology. Vol.42. No.1. P.13-18.

Churchill C.K., Valdés Á., Foighil D.Ó. 2014. Molecular and morphological systematics of neustonic nudibranchs (Mollusca: Gastropoda: Glaucidae: Glaucus), with descriptions of three new cryptic species // Invertebrate Systematics. Vol.28. P.174-195.

Drummond A.J., Rambaut A. 2007. BEAST: Bayesian evolutionary analysis by sampling trees // BMC evolutionary biology. Vol.7. No.1. P.214.

Ekimova I.A., Korshunova T.A., Schepetov D.M., Sanamyan N.P., Martynov A.V. 2015. Integrative systematics of Northern and Arctic nudibranchs of the genus Dendronotus (Mollusca, Gastropoda) with descriptions of three new species // Zoological Journal of the Linnean Society. Vol. 173. No.4. P.841-886.

Falniowski A., Szarowska M. 2012. Sequence-based species delimitation in the Balkan Bythinella MoquinTandon, 1856 (Gastropoda: Rissooidea) with general mixed Yule coalescent model // Folia Malacologica. Vol.20. No.2. P.111-120.

Folmer O., Black M., Hoeh W., Lutz R., Vrijenhoek R. 1994. DNA primers for amplification of mitochondrial cytochrome c oxidase subunit I from diverse metazoan invertebrates // Molecular Marine Biology and Biotechnology. Vol.3. P.294-299.

Fontaneto D. 2014. Molecular phylogenies as a tool to understand diversity in rotifers // International Review of Hydrobiology. Vol.99. No.1-2. P.178-187.

Fontaneto D., Flot J.F., Tang C.Q. 2014. Guidelines for DNA taxonomy, with a focus on the meiofauna // Marine Biodiversity. P.1-19.

Fujisawa T., Barraclough T.G. 2013. Delimiting species using single-locus data and the Generalized Mixed Yule-Coalescent Approach: a revised method and evaluation on simulated data sets // Systematics Biology. Vol.62. No.5. P.707-724.

Gofas S., Bouchet P. 2015. Dendronotus. Available from: World Register of Marine Species http://www. marinespecies.org/aphia.php? $\mathrm{p}=$ taxdetails $\& \mathrm{id}=$ 137885 (accessed 17 December 2015).

Goodheart J., Camacho Garcia Y., Padula V., Schödl M., Cervera J.L., Gosliner T.M., Valdés A. 2015. Systematics and biogeography of Pleurobranchus Cuvier, 1804 sea slugs (Heterobranchus: Nudipleura: Pleurobranchidae) // Zoological Journal of the Linnean Society. Vol.174. No.2. P.322-362.

Herbert P.D.N, Ratnasingham S., de Waard J.R. 2003. Barcoding animal life: cytochrome c oxidase subunit 1 divergences among closely related species // Proceedings of the Royal Society of London. Series B. Vol.270. P.96-99. 
Jörger K.M., Norenburg J.L., Wilson N.G., Schrödl M. 2012. Barcoding against a paradox? Combined molecular species delineations reveal multiple cryptic lineages in elusive meiofaunal sea slugs // BMC Evolutionary Biology. Vol.12. P.245.

Jörger K.M., Schrödl M. 2013. How to describe a cryptic species? Practical challenges of molecular taxonomy // Frontiers in Zoology. Vol.10. P.59.

Krug P.J., Vendetti J.E., Rodriguez A.K., Retana J.N., Hirano Y.M., Trowbridge C.D. 2013. Integrative species delimitation in photosynthetic sea slugs reveals twenty candidate species in three nominal taxa studied for drug discovery, plastid symbiosis or biological control // Molecular Phylogenetics and Evolution. Vol.69. P.1101-1119.

Lê H.L.V., Lecointre G., Perasso R. 1993. A 28S rRNA based phylogeny of the Gnathostomes: first steps in the analysis of conflict and congruence with morphologically based cladograms // Molecular Phylogenetics and Evolution. Vol.2. P.31-51.

Lemche H. 1948. Northern and Arctic tectibranch gastropods // Biol. Skr. Vol.5. No.3. P.1-136.

MacFarland F.M. 1966. Studies on opisthobranchiate mollusks of the Pacific Coast of North America // Memoirs of the California Academy of Science. Vol.6. P.1-546.

Martynov A.V. 1997. [Opisthobranch molluscs of Commander Islands with notes on fauna of Far-Eastern seas of Russia] // Donnaya fauna i flora Komandorskikh ostrovov [Bottom fauna and flora of Commander Islands]. Vladivostok: Dalnauka. P.230-241 [in Russian].

Martynov A.V. 1999. [Nudibranch mollusks (Mollusca: Opisthobranchia: Nudibranchia) of northwestern part of the Sea of Japan]. Ph.D. Dissertation. St. Petersburg: ZIN RAS. 325 p. [in Russian]

Martynov A.V. 2006. Clade Nudipleura // Yu.I. Kantor, A.V. Sysoev (eds.). Morskie i solonovatovodnie bryukhonogie molluski Rossii i sopredelnykh stran: illustrirovannyi katalog [Marine and brackish water Gastropoda of Russia and adjacent countries: an illustrated catalogue]. Moscow: KMK Scientific Press. P.267-294.

Martynov A. 2013. Clade Nudipleura // Sirenko B.I. (ed.). Issledovaniya fauny morei. Spisok vidov svobodnozhivuschikh bespozvonochnykh dalnevostochnykh morei [Explorations of the fauna of the seas. Checklist of species of free-living invertebrates of the Russian Far Eastern seas]. St. Petersburg: ZIN RAN. Vol.75(83). P.167-169.

Martynov A., Korshunova T., Sanamyan N., Sanamyan K. 2010. [Opisthobranch mollusks (Gastropoda: Opisthobranchia) from the coastal waters of Starichkov Island] // Biota ostrova Starichkov i prilegayuschei k nemu akvatorii Avachinskogo zaliva [Biota of Starichkov Island and adjacent waters of Avacha Gulf]. Proceedings of Kamchatka Branch of Pacific Institute of Geography, Far Eastern Division, Russian Academy of Sciences. Petropavlovsk-Kamchatsky: Kamchatpress. P.227-240 [in Russian].
Martynov A.V., Korshunova T.A. 2011. [Opisthobranch molluscs of the seas of Russia. A colour guide to their taxonomy and biology]. Moscow: Fiton Press. 240 p. [in Russian]

Martynov A.V., Sanamyan N.P., Korshunova T.A. 2015. [New data on the Opisthobranch molluscs (Gastropoda: Opisthobranchia) of waters of Commander islands and Far-Eastern seas of Russia] // Sokhranenie bioraznoobrazia Kamchatki i prilegayuschikh morei [Conservation of biodiversity of Kamchatka and coastal waters]. Proceedings of XV international scientific conference. Petropavlovsk-Kamchatsky, 18-19 November 2014. Petropavlovsk-Kamchatsky: Kamchatpress. P.55-69 [in Russian with English summary]

McDonald G.R. 1983. A review of the nudibranchs of the California coast // Malacologia. Vol.24. P.114-276.

McDonald G.R. 2009. Nudibranch Systematic Index, 2nd Edition. Available at: http://repositories.?cdlib.?org/ ?ims/?Nudibranch_?Systematic_?Index_?second ?edition.

Neusser T.P., Jörger K.M., Schrödl M. 2011. Cryptic species in tropic sands-Interactive 3D anatomy, molecular phylogeny and evolution of meiofaunal Pseudunelidae (Gastropoda, Acochlidia) // PLoS One. Vol. 6. No.8. P.e23313.

Ortigosa D., Pola M., Carmona L., Padula V., Schrödl M., Cervera J.L. 2014. Redescription of Felimida elegantula (Philippi, 1844) and a preliminary phylogeny of the European species of Felimida (Chromodorididae) // Journal of Molluscan Studies. Vol.80. No.5. P.541550.

Padula V., Araújo A.K., Matthews-Cascon H., Schrödl M. 2014. Is the Mediterranean nudibranch Cratena peregrina (Gmelin, 1791) present in the Brazilian coast? Integrative species delimitation and description of Cratena minor n. sp. // Journal of Molluscan Studies. Vol.80. No.5. P.575-584.

Palumbi S., Martin A., Romano S., McMillan W.O., Stice L., Grabowski G. 2002. The simple fool's guide to PCR, version 2. Department of Zoology, University of Hawaii, Honolulu. 12 p.

Pola M., Gosliner T.M. 2010. The first molecular phylogeny of cladobranchian opisthobranchs (Mollusca, Gastropoda, Nudibranchia) // Molecular Phylogenetics and Evolution. Vol.56. P.931-941.

Pola M., Stout C. 2008. Descriptions of the first two tropical Indo-Pacific species of Dendronotus (Gastropoda: Nudibranchia) with new data for the poorly known species Dendronotus gracilis Baba, 1949 // Zootaxa. Vol.1960. P.45-66.

Pons J., Barraclough T.G., Gomez-Zurita J., Cardoso A., Duran D.P., Hazell S., Kamoun S., Sumlin W.D., Vogler A.P. 2006. Sequence-based species delimitation for the DNA taxonomy of undescribed insects // Systematic biology. Vol.55. No.4. P.595-609.

Prévot V., Jordaens K., Sonet G., Backeljau T. 2013. Exploring species level taxonomy and species delimitation methods in the facultatively self-fertilizing land snail genus Rumina (Gastropoda: Pulmonata) // PloS One. Vol.8. No.4. P.e60736. 
Puillandre N., Lambert A., Brouillet S., Achaz G. 2012. ABGD, Automatic Barcode Gap Discovery for primary species delimitation // Molecular Ecology. Vol.21. P.1864-1877.

Puslednik L., Serb J.M. 2008. Molecular phylogenetics of the Pectinidae (Mollusca: Bivalvia) and effect of increased taxon sampling and outgroup selection on tree topology // Molecular Phylogenetics and Evolution. Vol.48. P.1178-1188.

Robilliard G.A. 1970. The systematics and some aspects of the ecology of the genus Dendronotus // Veliger. Vol.12. P.433-479.

Robilliard G.A. 1975. The nudibranch Dendronotus frondosus: is it one species or four? // Festivus. Vol.68. P.44-47.

Roginskaya I.S. 1987. [Order Nudibranchia Blainville, 1814] // Scarlato O.A. (ed.). Molluski Belogo morya. Opredeliteli po faune SSSR [Molluscs of the White Sea. Keys to the Fauna of USSR]. Leningrad: Nauka. P.155-201 [in Russian]

Ronquist F., Huelsenbeck J.P. 2003. MRBAYES 3: Bayesian phylogenetic inference under mixed models // Bioinformatics. Vol.19. P.1572-1574.

Schrödl M. 2003. Sea slugs of southern America. Hackenheim: Conch Books. $165 \mathrm{p}$

Stout C.C, Pola M., Valdés A. 2010. Phylogenetic analysis of Dendronotus nudibranchs with emphasis on northeastern Pacific species // Journal of Molluscan Studies. Vol.76. P.367-375.

Stout C.C., Wilson N.G., Valdés A. 2011. A new species of deep-sea Dendronotus Alder \& Hancock (Mollus- ca: Nudibranchia) from California, with an expanded phylogeny of the genus // Invertebrate Systematics. Vol.25. P.60-69.

Sukumaran J., Holder M.T. 2010. DendroPy: a Python library for phylogenetic computing // Bioinformatics. Vol.26. P.1569-1571.

Tamura K., Stecher G., Peterson D. 2013. MEGA6: Molecular Evolutionary Genetics Analysis version 6.0. // Molecular Biology and Evolution. Vol.30. P.27252729.

Thollesson M. 1998. Discrimination of two Dendronotus species by allozyme electrophoresis and the reinstatement of Dendronotus lacteus (Thompson, 1840) (Nudibranchia, Dendronotoidea) // Zoologica Scripta. Vol.27. P.189-195.

Wägele H., Klussmann-Kolb A., Verbeek E., Schrödl M. 2013. Flashback and foreshadowing - a review of the taxon Opisthobranchia // Organism Diversity and Evolution. Vol.14. P.133-149.

Williams S., Apte D., Ozawa T., Kaligis F., Nakano T. 2011. Speciation and dispersal along continental coastlines and island arcs in the Indo-West Pacific turbinid gastropod genus Lunella // Evolution. Vol.65. No.6. P.1752-1771.

Zwickl D.J. 2006. Genetic algorithm approaches for the phylogenetic analysis of large biological sequence datasets under the maximum likelihood criterion. Ph.D. Dissertation. Austin: The University of Texas.

Responsible editor E.N. Temereva 